\title{
Late Jurassic facies architecture of the Złoczew Graben: implications for evolution of the tectonic-controlled northern peri-Tethyan shelf (Upper Oxfordian-Lower Kimmeridgian, Poland)
}

\author{
Marcin Krajewski $^{1} \cdot$ Piotr Olchowy $^{1} \cdot$ Ireneusz Felisiak $^{1}$
}

Received: 4 September 2015 / Accepted: 17 November 2015 / Published online: 10 December 2015

(C) The Author(s) 2015. This article is published with open access at Springerlink.com

\begin{abstract}
In recent years, numerous wells have been completed in the area of the Zloczew Graben. Drill cores and data collected from wells have led to the recognition of an Upper Oxfordian-Lowermost Kimmeridgian sequence and to the construction of a 3D model of the graben with distribution of facies. Six facies types were distinguished, composed of numerous microfacies representing outer-, middle-, and inner-ramp depositional systems. The boundary of the Planula/Platynota zones is indicated by the transition from mid-inner carbonate ramp facies to mixed, carbonate-siliciclastic outer-ramp facies, as well as by appearance of debrites and calciturbidites. The distribution of gravity-flow deposits reflects the pattern of fault zones of the Złoczew Graben and their Late Jurassic activity. Comparison of Oxfordian-Lowermost Kimmeridgian facies types from central and southern Poland enabled the reconstruction of the general facies architecture in the Polish part of the northern peri-Tethyan shelf belonging to the Małopolska Block. The distribution of Upper Oxfordian-Lowermost Kimmeridgian facies follows the block structure of the basement and was controlled by reactivation of Paleozoic tectonic blocks in the Late Jurassic. The results of studies in the Polish basin correspond well to Upper Oxfordian-Lower Kimmeridgian sequences known from the ramp systems of western Europe where the basic change in deposition, from a carbonate ramp towards mixed, carbonate-siliciclastic sedimentation, was related to both North Atlantic and western European tectonics.
\end{abstract}

Piotr Olchowy

piotrolch@geol.agh.edu.pl

1 Faculty of Geology, Geophysics and Environmental Protection, AGH University of Science and Technology, Al. Mickiewicza 30, 30-059 Kraków, Poland
Keywords Ramp facies and microfacies - Stromatactis . Synsedimentary tectonism - Late Jurassic grabens . Oxfordian-Kimmeridgian $\cdot$ Poland

\section{Introduction}

The Złoczew Graben (central Poland) is located at the boundary of the Złoczew High and the Wielun Upland (Fig. 1). During the Late Jurassic Oxfordian-Lower Kimmeridgian, the Polish part of the shelf bordered a vast, epicontinental sea that rimmed the Tethys Ocean from the north (e.g., Ziegler 1990; Matyszkiewicz 1997b; Golonka 2004). Reconstruction of the Late Jurassic facies architecture of this broad, epeiric carbonate shelf located in central and southern Poland is difficult and controversial due to insufficient knowledge of microfacies development and facies distribution. The concepts of depositional system development are based mostly on data from Upper Jurassic outcrops located in the northeastern and southwestern margins of the Holy Cross Mountains and KrakówCzęstochowa, and Wieluń uplands (Fig. 1) (e.g., Kutek et al. 1977; Matyja et al. 1989; Matyszkiewicz et al. 2006a and references therein). The knowledge of facies development of Upper Jurassic sediments in the remaining areas of central and southern Poland is based on rarely published data from wells (e.g., Gutowski et al. 2005; Złonkiewicz 2009; Krajewski et al. 2011a and references therein). In the Oxfordian, the study area formed the eastern part of an epicontinental ramp system that developed in western and central Europe (e.g., Leinfelder et al. 1996; Matyszkiewicz 1997b; Bádenas and Aurell 2001; Olóriz et al. 2003; Reolid et al. 2005; Olivier et al. 2008). The Upper Oxfordian deposits from central and southern Poland were assigned to the deep-water open shelf, so-called sponge megafacies 
(Matyja et al. 1989; Gutowski et al. 2005). To the northeast, this megafacies passes into sediments of a shallow-water platform prograding from the Lublin area located some $200 \mathrm{~km}$ to the east. In the Late Oxfordian, the front of that platform approached the southwestern margin of the Holy Cross Mountains (Fig. 1).

The most important factors controlling deposition in these areas were: sea-level changes, diverse basement structures, and synsedimentary tectonics (e.g., Kutek 1994; Gutowski et al. 2005; Matyszkiewicz et al. 2006a, b, 2012; Krajewski et al. 2011a, 2014). In the Late Jurassic depositional system of both central and southern Poland, the Oxfordian/Kimmeridgian boundary was one of the most important and best-marked stages in the sedimentation history of the Polish Basin. This stage included the extinction of reefs and the intensive development of deep-water, lime mudstone and marly facies (e.g., Kutek 1994; Matyszkiewicz 1996, 1997b; Gutowski et al. 2005; Krajewski et al. 2014).

In the area of the Złoczew Graben and its vicinity, covering about a $15 \times 3-\mathrm{km}$ strip of land, nearly 200 wells have reached the Upper Jurassic succession in the exploration

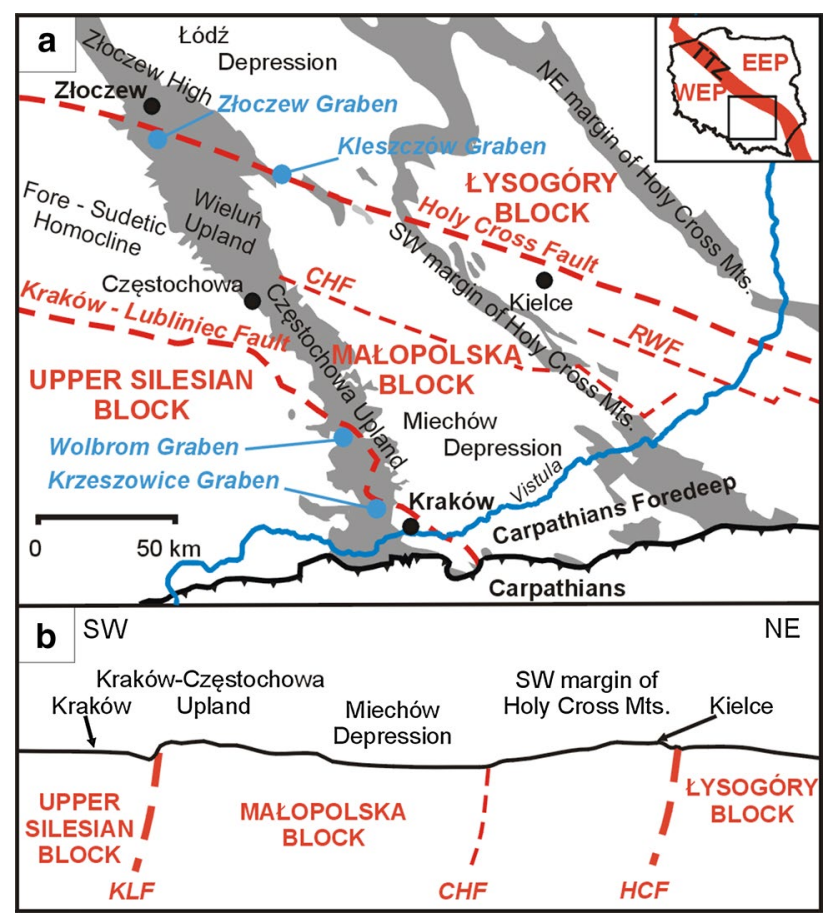

Fig. 1 a Location map of the study areas with Upper Jurassic outcrops and sub-Cenozoic Jurassic subcrops (grey) in southern and central Poland (after Pożaryski et al. 1979, modified and simplified). Tectonic structures (in red) after Buła and Habryn (2011) and Krzywiec (2006). KLF Kraków-Lubliniec Fault, $H C F$ Holy Cross Fault, $C H F$ Chmielnik Fault, RWF Ryszkowa Wola Fault, TTZ Teisseyre-Tornquist Zone, EEP East European Platform, WEP West European Platform. $\mathbf{b}$ Sketch of main geographical units and main tectonic units in the Paleozoic basement for a lignite deposit (Borowicz et al. 2007). Such a dense grid along with the precise location and depths of the wells, and full-depth coring, has enabled the study of facies and microfacies development of Upper Jurassic sediments in the area and the visualization of facies distribution in a 3D model of the Złoczew Graben. The aim of this paper is to document the Upper Jurassic facies and microfacies from the Złoczew Graben and to make comparisons to equivalent sediments from the adjacent areas in southern and central Poland.

\section{Geological setting}

The Złoczew Graben is located at the boundary of two trans-regional tectonic units of Poland: the ForeSudetic Homocline and the Łódź Depression (Fig. 1). The Złoczew Graben occurs within the northeast border of the Małopolska Block, which forms the margin of the West European Platform (e.g., Gutowski and Koyi 2007; Żelaźniewicz et al. 2011; Buła and Habryn 2011). The Małopolska Block occupies a large part of central and southern Poland (Fig. 1). In its southwestern part, both the Middle and Upper Jurassic strata commonly rest directly upon Cambrian, Ordovician, and Silurian deposits (Buła and Habryn 2010, 2011; Żelaźniewicz et al. 2011). In its central and northeastern parts, Jurassic strata cover Devonian, Carboniferous, and Triassic deposits as a result of uplift of the southwestern part of the block.

The Upper Jurassic deposits of the Złoczew High comprise limestone and marl dated as Oxfordian-Lower Kimmeridgian (Deczkowski 1977; Deczkowski and Gajewska 1983). The oldest sediments are Lower Oxfordian nodular limestone with stromatolites, which grade up into alternating marl and limestone with sponges and ammonites (Deczkowski 1977; Deczkowski and Gajewska 1983), followed by Middle and Upper Oxfordian, thin-bedded, platy limestone as well as massive and bedded sponge limestone with chert and marl interbeds. The youngest marl and limestone belong to the Lower Kimmeridgian (Deczkowski 1977; Deczkowski and Gajewska 1983). The thickness of the Upper Jurassic succession in the Złoczew Graben reaches $290 \mathrm{~m}$ (Biesiec 1 and 2 wells).

The Złoczew Graben is $13 \mathrm{~km}$ long, up to $1.5 \mathrm{~km}$ wide, and from 200 to $350 \mathrm{~m}$ deep. The recent geometry of the graben originated in the Miocene. The dislocations parallel to the graben axis are steep faults with throws from 25 to $200 \mathrm{~m}$. These are accompanied by transverse faults (Deczkowski and Gajewska 1983; Borowicz et al. 2007; Dukacz 2013). The graben is filled with Paleogene and Neogene sediments, and the whole area is covered by Pleistocene sand and boulder clay. 


\section{Materials and methods}

Preliminary data on Jurassic sediments from the Złoczew Graben can be found in unpublished reports on 110 wells completed before 2011 and in geological assessment reports of the Złoczew Graben. The principal research tool was microscopic examination of sections from 125 fullcored wells completed in the years 2011-2012, arranged in a grid shown in Fig. 2. From samples collected in drill cores, both polished slabs (Fig. 5) and thin-sections (Figs. 6, 7, 8) were made, and these were the basis for sedimentological studies. Upper Jurassic sediments, up to $130 \mathrm{~m}$ thick, were encountered in all studied cores. Lithology and thickness of the older Oxfordian sediments are known from previous wells (see e.g., Deczkowski 1977; Deczkowski and Gajewska 1983).

Fieldwork provided the lithological columns and samples for microfacies studies. Generally, six facies types were distinguished (FT 1-6) in which numerous microfacies were identified (Fig. 2). The analysis of facies distribution was based upon lithological columns and structural maps, and visualized as a 3D model of the Złoczew Graben (Dukacz 2013). Modeling utilized the Triangular Irregular Networks (TIN) numerical model for the top surface of the Jurassic strata, using the ArcGis software. The model presents the locations of wells, top surface of Upper Jurassic deposits and distribution of the distinguished facies (Figs. 2, 3). In marly limestone and marl, the $\mathrm{CaCO}_{3}$ contents were analyzed.

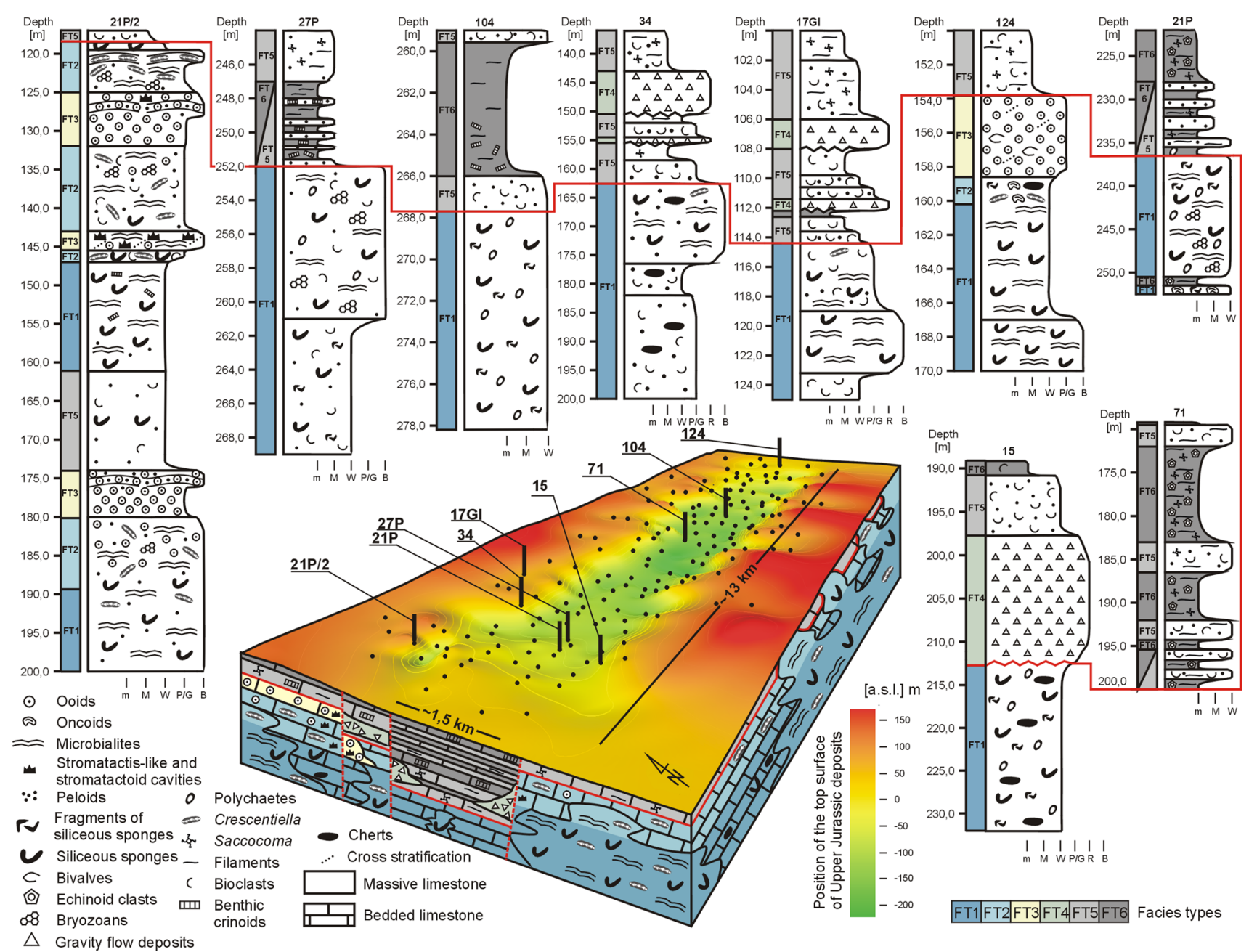

Fig. 2 3D model of the Złoczew Graben with location of wells (dark dots), distribution of facies and examples of lithological columns with facies types 1-6. Black vertical lines indicate location of lithological columns. Red dotted lines on the 3D model indicate main faults bordering the Złoczew Graben. The red lines on the lithological columns and 3D model of Złoczew Graben indicate the correlation horizon, which represents the transition from the mid-ramp to the outer-ramp system. The width of the graben is ca. $1.5 \mathrm{~km} . m$ marl, $M$ mudstone, $W$ wackestone, $P$ packstone, $G$ grainstone, $B$ boundstone, $R$ rudstone 


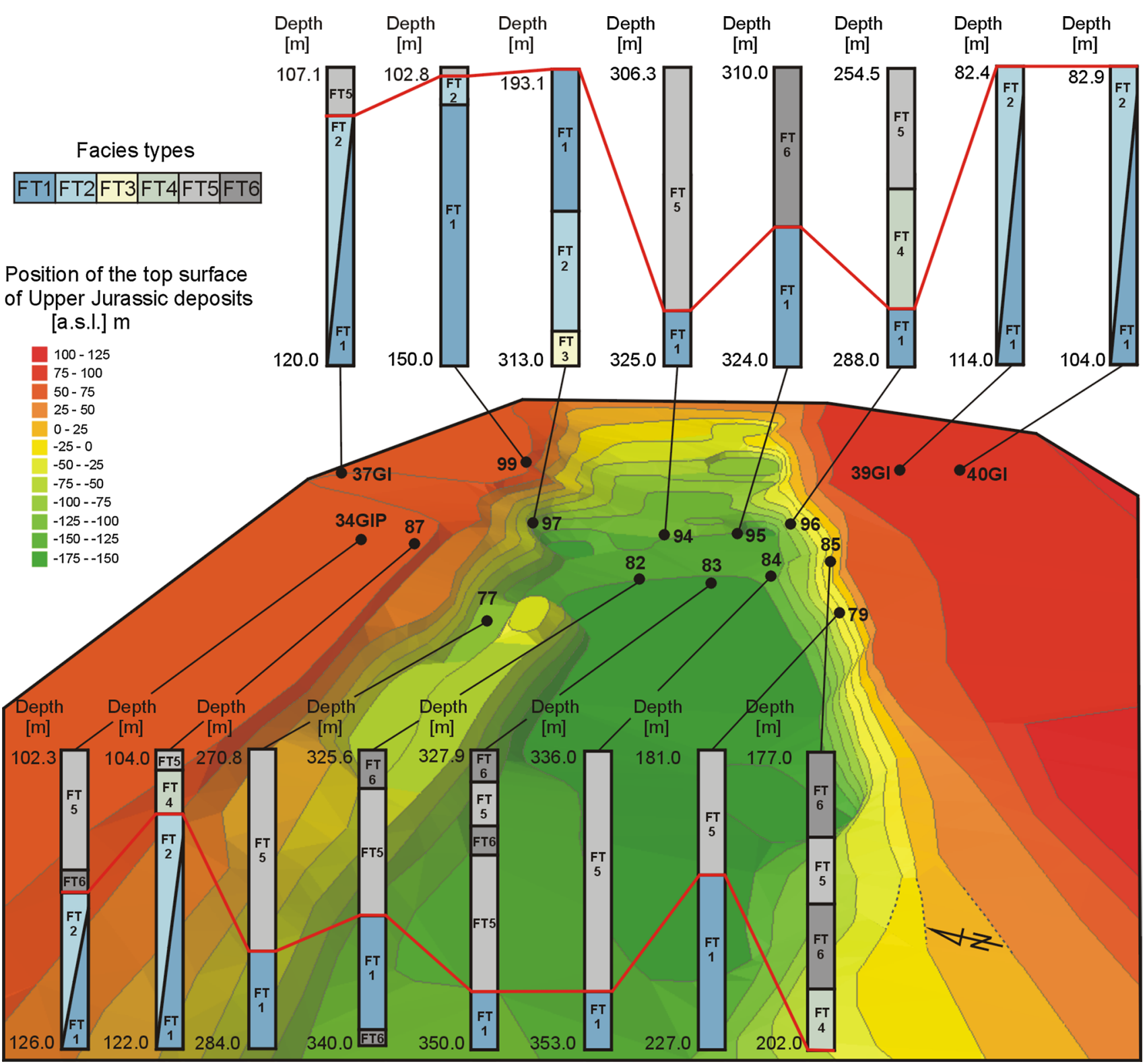

Fig. 3 The northeastern part of the Złoczew Graben with distribution of facies types in the wells oriented in transverse lines. The red line on the columns with distribution of facies types and 3D model of the

\section{Results}

\section{Stratigraphy}

Microfossil studies support the earlier stratigraphic subdivisions (Deczkowski 1977; Deczkowski and Gajewska 1983) indicating the Upper Oxfordian and Lowermost Kimmeridgian ages (e.g., Olszewska et al. 2012). The foraminifer assemblage includes, among others: Sievoides kocyigti, Reophax Helvetius, Protomarssonella jurassica, Paalzowella turbinella, Rumanolina feifeli, Gaudryina sp., Mohlerina basiliensis, Haghimashella arcuata, Protopeneroplis
Złoczew Graben area indicate the correlation horizon, which represents the transition from the mid-ramp to the outer-ramp system

strata, and Nautiloculina cf. Bronnimanni. Moreover, calcareous dinocysts were identified: Colomisphaera lapidosa, Stomiosphaera moluccana, Colomispharea af. heliosphaera, Colomisphaera aff. Radiata (Vogler), Colomisphaera misolensis Vogler, Stomiosphaera minutissima and Colomisphaera cf. Peniniensis (Borza). The presence of Lower Kimmeridgian (Platynota zone) deposits is confirmed by the marker horizon with hiatus concretions observed in the Złoczew Graben, which is of regional correlative importance in central Poland (Krajewski et al. 2014). Additionally, the observed sedimentary sequences (Fig. 4) correspond well to Upper Jurassic sequences from 


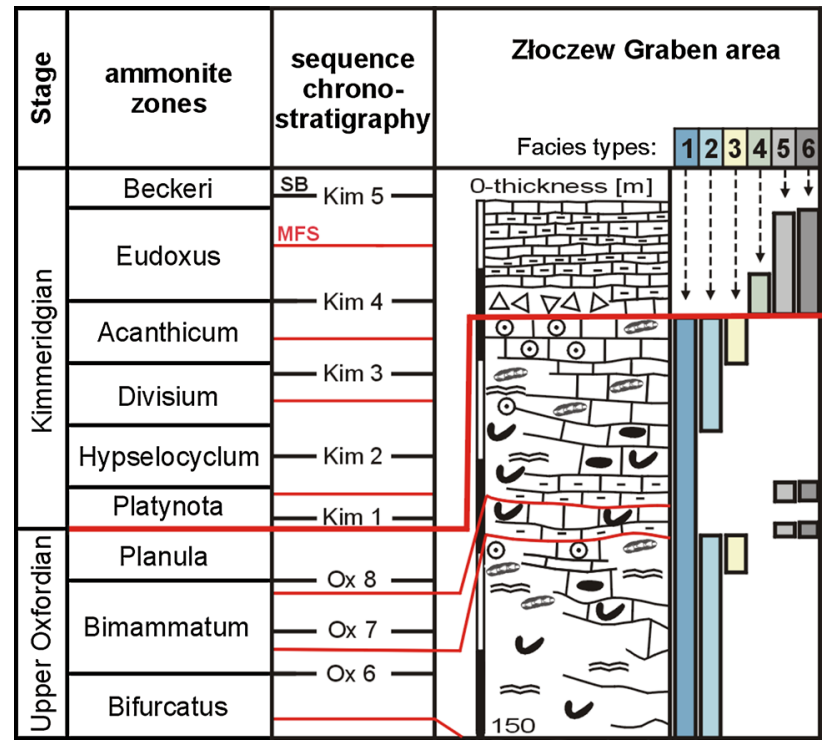

Fig. 4 Stratigraphic position of the Upper Jurassic deposits from the Złoczew Graben area. SB sequence boundary, $M F S$ maximum flooding surface. Ages of ammonite subzone boundaries and of sequence boundaries according to Hardenbol et al. (1998). Description as on Fig. 2

adjacent areas (e.g., Wierzbowski et al. 1983; Matyszkiewicz 1997b; Matyszkiewicz et al. 2006a, 2015; Krajewski et al. 2011a) and the Ox-Kim sequence boundaries identified by Hardenbol et al. (1998).

\section{Facies types}

\section{FT 1: Microbial-sponge limestone}

This facies type includes massive carbonate buildups and bedded limestone. In the hanging-wall blocks of the Złoczew Graben, the FT 1 facies grades up into the FT 2 facies, whereas in the central parts of the graben, the FT 1 passes upwards into the FT 5 and FT 6 facies (Fig. 2).

The massive limestone observed in the hanging walls of the graben reach thicknesses up several tens of meters. These are mostly microbial-sponge boundstone and bioclastic wackestone/packstone (Fig. 2; Table 1). Dish-like siliceous sponges (Lithistida and Hexactinellida) overgrown by microbialites form the frameworks of that limestone (Fig. 6a). Microbialites are dominated by fine crusts of dense micrite, clotted thrombolites, and peloidal stromatolites (sensu Schmid 1996) (Fig. 6b, c). The bioclastic wackestone/packstone is composed mostly of peloids, fragments of siliceous sponges, and numerous fine bioclasts. Abundant are microencrusting organisms, usually bryozoans, benthic foraminifers (Nubecularia, Bullopora), and serpulids. The agglutinating annelid Terebella lapilloides is common. In the upper parts of the FT 1 sequence,
Crescentiella microencrusters are common (Tubiphytes in older literature) (Fig. 6c).

Massive limestone in the Złoczew Graben does not occur in all studied wells, which indicates its rather limited lateral extent (Fig. 2). The thickness does not exceed several meters. The main builders are siliceous sponges whereas microbialites (layered thrombolites and leiolites) are less common. Other fossils are bryozoans, serpulids, and echinoderms. The massive limestone contains thin (up to $0.5 \mathrm{~cm}$ ) laminae of marly limestone and lime mudstone.

The bedded limestone can be thick- or thin-bedded. The thick-bedded variety with chert resembles the massive limestone in hand specimen. The essential differences are microfacies features: bedded limestone contains fewer benthic organisms but more bioclastic wackestone/packstone. The thin-bedded limestone occurs in the graben (Fig. 2). The microfacies is mainly peloidal-bioclastic wackestone and packstone with fragments of siliceous sponges, fragments of ammonites, and bioturbation (Thalassinoides and Chondrites). Similar to the massive facies, the bedded limestone of the down-thrown central part of the graben is in some cases intercalated with marly limestone and marl.

Facies interpretation The FT 1 is a typical microbialsponge facies widely distributed over the whole northern shelf of the Tethys Ocean (see e.g., Keupp et al. 1990; Leinfelder et al. 1996; Matyszkiewicz 1997b; Schmid et al. 2001; Olóriz et al. 2003; Olivier et al. 2004; Reolid et al. 2005). Both the massive and the thick-bedded limestone represent microbial-sponge reefs or biostromes. The massive limestone seen in the graben forms a low-relief space cluster reef sensu Riding (2002) and shows a close relationship to the initial 'loose' bioherms described from the Kraków-Częstochowa Upland (Trammer 1989; Matyszkiewicz et al. 2012). The intercalations of marly limestone and lime mudstone are products of deep-water deposition in local depressions between the reef complexes. Similar, deep-water sponge-microbial reefs were described from the Swabian and Franconian Alps (Keupp et al. 1990; Schmid et al. 2001; Olivier et al. 2004).

The FT 1 facies was deposited in a distal, mid-ramp setting, mostly a low-energy, nutrient-rich environment (e.g., Keupp et al. 1993; Olóriz et al. 2003; Olivier et al. 2004). The growth of microbialites and their diversity were controlled mainly by sedimentation rate and energy level (e.g., Keupp et al. 1993; Leinfelder et al. 1996; Matyszkiewicz et al. 2012), which reflect local conditions unaffected by significant changes in sea-water chemistry (Matyszkiewicz et al. 2012). Common microencrusters, mostly benthic microbial communities, serpulids, bryozoans, and foraminifers, indicate a low-energy environment, low sedimentation rate and low terrigenous influx (e.g., Reolid and Gaillard 2007). Terebella lapilloides is commonly observed in Upper Jurassic reefs and represents a low-energy setting 


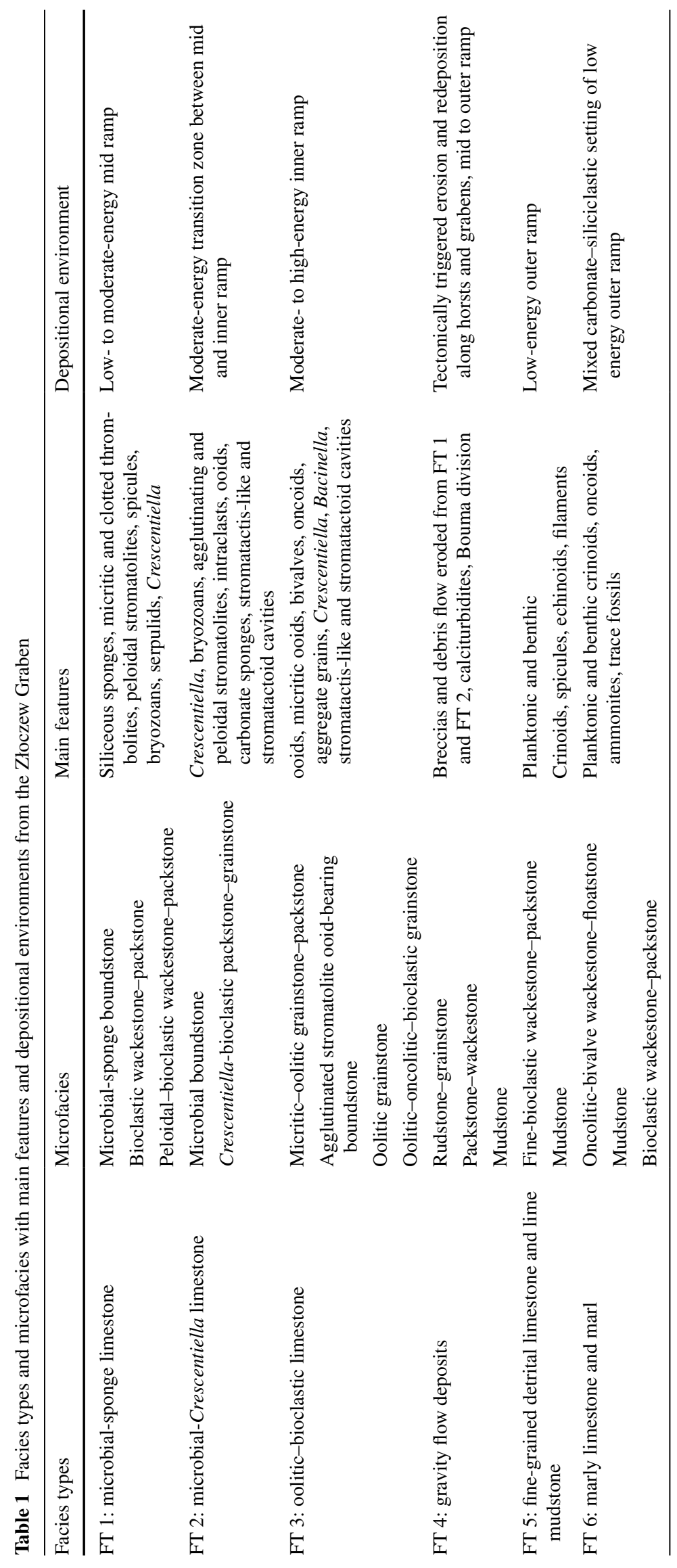


under dysoxic conditions (e.g., Reolid et al. 2005; Kaya and Altiner 2014). The presence of phototrophic microbialites and Crescentiella in thick, massive and bedded limestone, indicates paleodepths above storm-wave base, i.e., around 40-60 m (e.g., Keupp et al. 1993; Aurell et al. 1995; Leinfelder et al. 1996; Matyszkiewicz 1997b; Krajewski 2000).

\section{FT 2: Microbial-Crescentiella limestone}

This facies type occurs in both the massive and bedded limestone located along the margins of the Złoczew Graben (Fig. 2). The FT 2 grades up into the FT 3 and/or FT 5 (Fig. 2). Dominating components of FT 2 are: very abundant Crescentiella morronensis (Crescenti) and bryozoans (Table 1; Fig. 6c, d). Crescentiella occurs as individuals or colonial assemblages in which the individual forms are commonly connected with cyanophycean crusts (Fig. 6d). Thickness of colonies may reach some tens of centimeters and their lateral extensions are presumably much larger (cf. Matyszkiewicz and Felisiak 1992; Krajewski 2000). This association includes two microfacies varieties: (1) microbial boundstone and (2) Crescentiella-bioclastic packstone-grainstone (Fig. 6d, e). Apart from Crescentiella, agglutinated and peloidal stromatolites are present. Detrital components in stromatolites comprise fine bioclasts, peloids, and ooids. In Crescentiella-bioclastic packstonegrainstone, Crescentiella is usually accompanied by numerous, crushed bioclasts dominated by randomly distributed bivalve shells, calcareous sponges, intraclasts, and, less common, fragments of siliceous sponges. In the lower portions of FT 2, Crescentiella coexists with siliceous sponges and thrombolites, which gradually disappear upwards with the increasing amounts of non-skeletal coated grains, including oncoids and ooids (Fig. 6e, f). Close to the graben margin, FT 2 contains stromatactis-like cavities (sensu Matyszkiewicz 1997a) and stromatactoid cavities (cf. Neuweiler et al. 2001) (Figs. 5b, 6f). Their characterization is presented below, in the description of FT 3.

Facies interpretation Limestone with numerous Crescentiella was included in the Tubiphytes-Terebella association (Leinfelder et al. 1996). Crescentiella represents symbiosis between nubecularid foraminifers and cyanophyceans (e.g., Senowbari-Daryan et al. 2008; Pleş et al. 2013). Commonly, the individual specimens in life position are connected with cyanophycean crusts, forming a kind of colony, which builds micro-constructions (e.g., Schlagintweit and Gawlick 2008; Krajewski 2008; SenowbariDaryan et al. 2008). Such an association is common in a mid-ramp setting (e.g., Leinfelder et al. 1996). Such sediments were common in many parts of Late Jurassic, openmarine, shallow-water, epicontinental environments of the Tethyan Realm (e.g., Leinfelder et al. 1996; Matyszkiewicz 1997b; Krajewski and Olszewska 2006; Senowbari-Daryan et al. 2008; Pleş et al. 2013; Chatalov et al. 2015; Kaya and Altiner 2015 and references therein). FT 2 is a transitional facies between mid-ramp and inner-ramp facies. Common grainstone in this association indicates reworking of material close to the wave base. A common feature of FT 2 as well as FT 1 and FT 3 is the presence of Crescentiella in transition zones between the facies. Both the skeletal and non-skeletal components of FT 2, including thick-shelled bivalves, oncoids, and ooids indicate an environment close to the fair-weather wave base (e.g., Matyszkiewicz and Felisiak 1992; Krajewski 2000; Matyszkiewicz et al. 2006a).

\section{FT 3: Oolitic-bioclastic limestone}

This facies type is encountered in wells located along the northwestern and western margins of the Złoczew Graben where it overlies the FT 2 facies (Fig. 2). In places, it occurs as redeposited sediment within the graben (e.g., No. 97 well) (Fig. 3). The FT 2-FT 3 transition is gradual over $\sim 20 \mathrm{~cm}$ where the percentage of Crescentiella decreases and that of ooids increases. Four types of microfacies were distinguished (Table 1; Fig. 7): (1) micriticoolitic grainstone-packstone, (2) agglutinated stromatolite ooid-bearing boundstone, (3) oolitic grainstone, and (4) oolitic-oncolitic-bioclastic grainstone. The micritic-oolitic grainstone-packstone and the agglutinated stromatolite ooid-bearing boundstone can be observed in the lower part of the FT 3 succession. Up the succession, these are replaced by oolitic grainstone and oolitic-oncolitic-bioclastic grainstone.

Micritic-oolitic grainstone-packstone is composed of small $(<0.5 \mathrm{~mm})$ ooids, small intraclasts, and oncoids accompanied by abundant bioclasts, brachiopods, gastropods, bivalves, and echinoids (Fig. 7a). Commonly, the sediment is stabilized by microbial crusts.

Agglutinated stromatolite ooid-bearing boundstone is composed of ooids bounded by microbialites in which stromatactis-like and stromatactoid cavities are observed (Fig. 7b, c). This microfacies occurs only close to the margins of the Złoczew Graben, in its hanging-wall blocks (Fig. 2). Stromatolites are commonly discontinuous and laminae are deformed (Fig. 7b). Dominating components are radial ooids, up to $1 \mathrm{~mm}$ across, micritic ooids, fine bioclasts, and peloids. Thickness of detrital sediments enclosed between microbial laminae may reach up to $1 \mathrm{~cm}$ but is usually $<2 \mathrm{~mm}$ (Fig. 7c).

In this microfacies, stromatactis-like and stromatactoid cavities are common (Fig. 2). Cavities reach $2 \mathrm{~cm}$ in length and are up to $0.5 \mathrm{~cm}$ high (Fig. $5 \mathrm{~b}$ ). Stromatactoid cavities are smaller, up to about $0.5 \mathrm{~cm}$ wide, and $3 \mathrm{~mm}$ high. Both types of cavity occur as individuals or locally they 


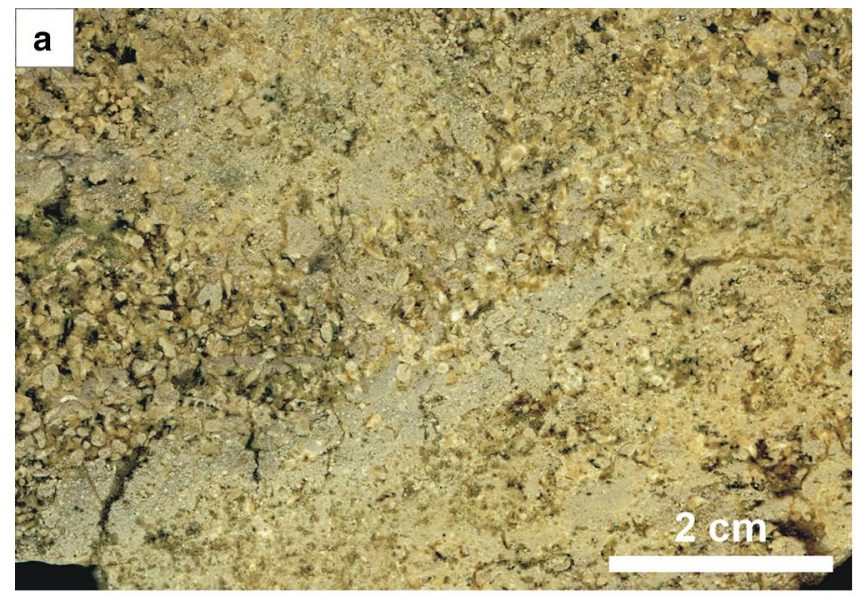

d
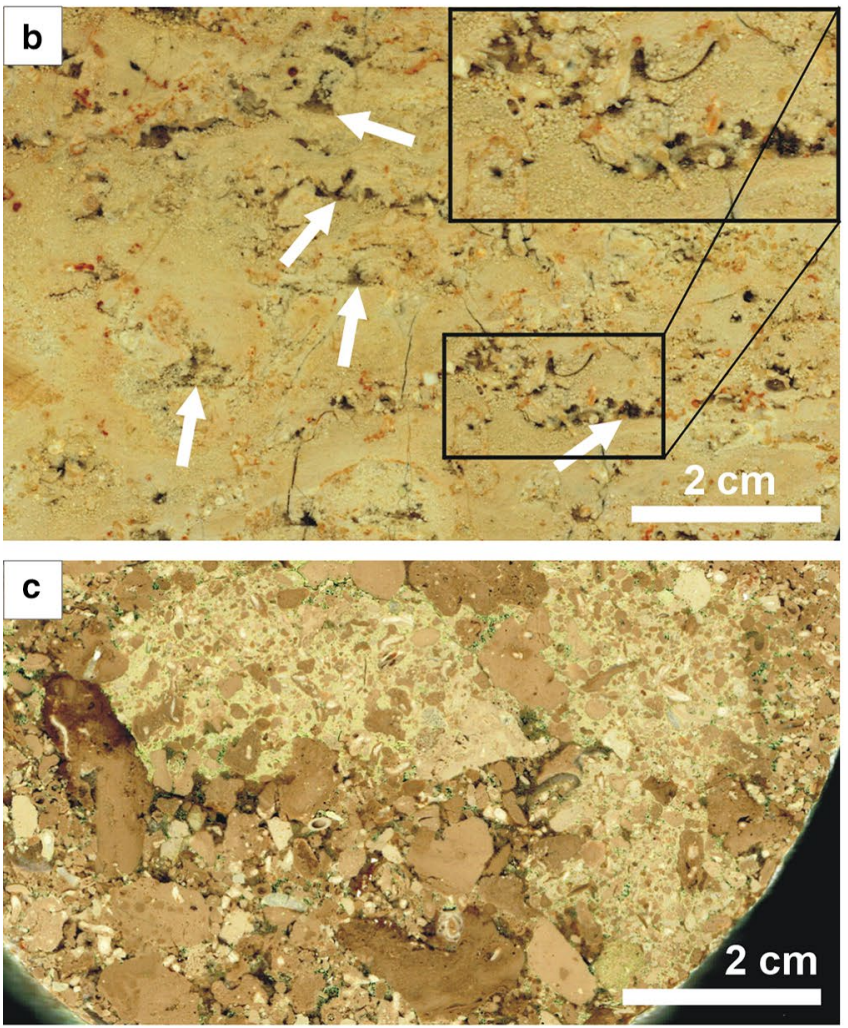

\section{$T_{E}$}
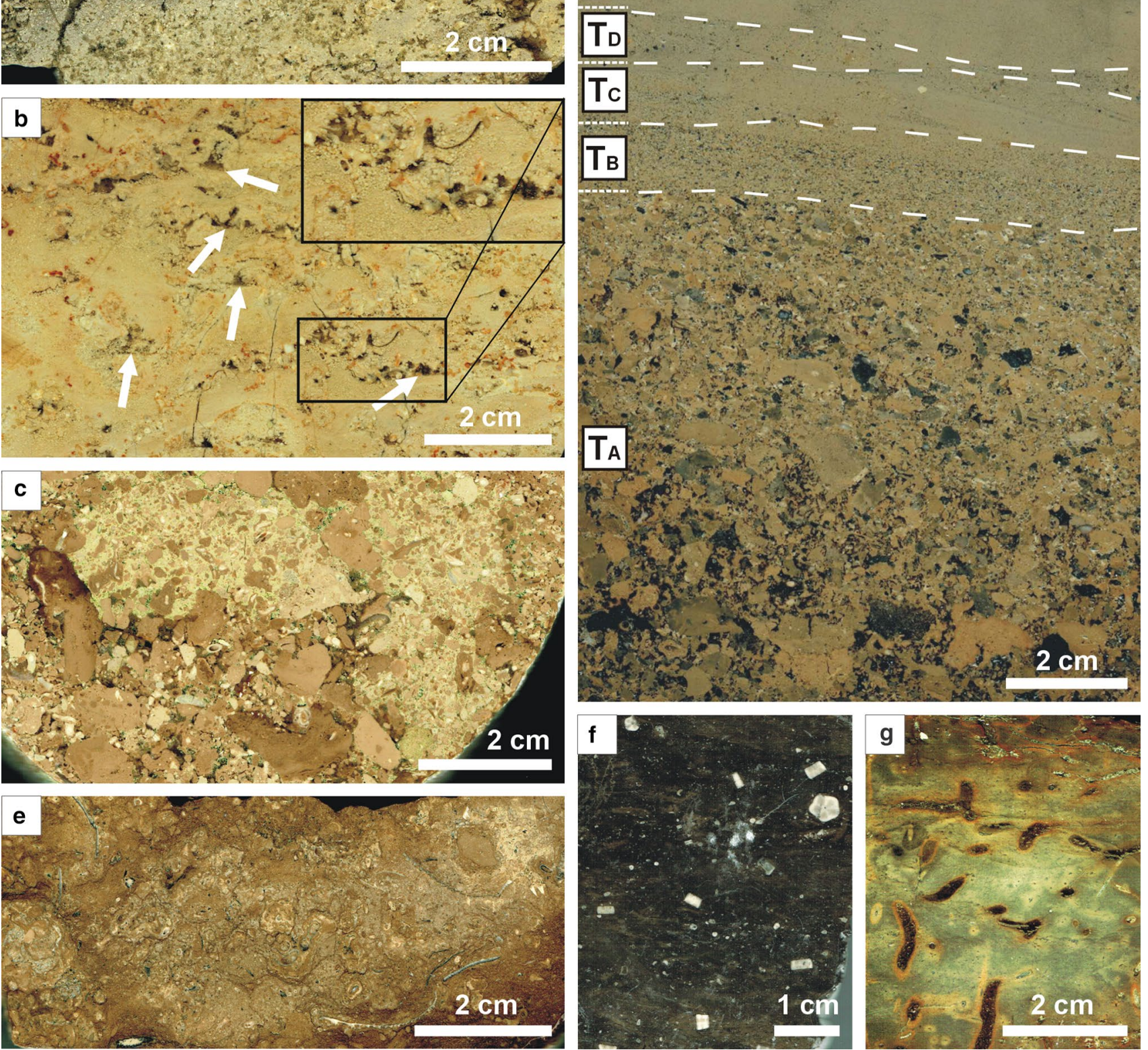

Fig. 5 Polished slabs from Upper Jurassic deposits. a Detrital limestone with numerous Crescentiella and bioclasts (FT 2). 116 well, depth $188.0 \mathrm{~m}$. b Microbial-Crescentiella limestone with numerous stromatactis-like and stromatactoid cavities (white arrows) (FT 2). 21P/2 well, depth 143.6 m. c Gravity-flow deposits (synsedimentary breccia) with numerous irregular clasts of different facies types (FT

4). 17GI well, depth $112.0 \mathrm{~m}$. d Gravity-flow deposits with visible Bouma divisions (FT 4). N43 well, depth 262.0 m. e Marly limestone with numerous irregular oncoids and bivalves (FT 6). 86P well, depth $328.0 \mathrm{~m}$. f Marl with numerous fragments of benthic crinoids (FT 6). 53 well, depth $307.0 \mathrm{~m}$. g Marly limestone with numerous burrows (FT 6). P(H-1/1) well, depth $238.6 \mathrm{~m}$ 

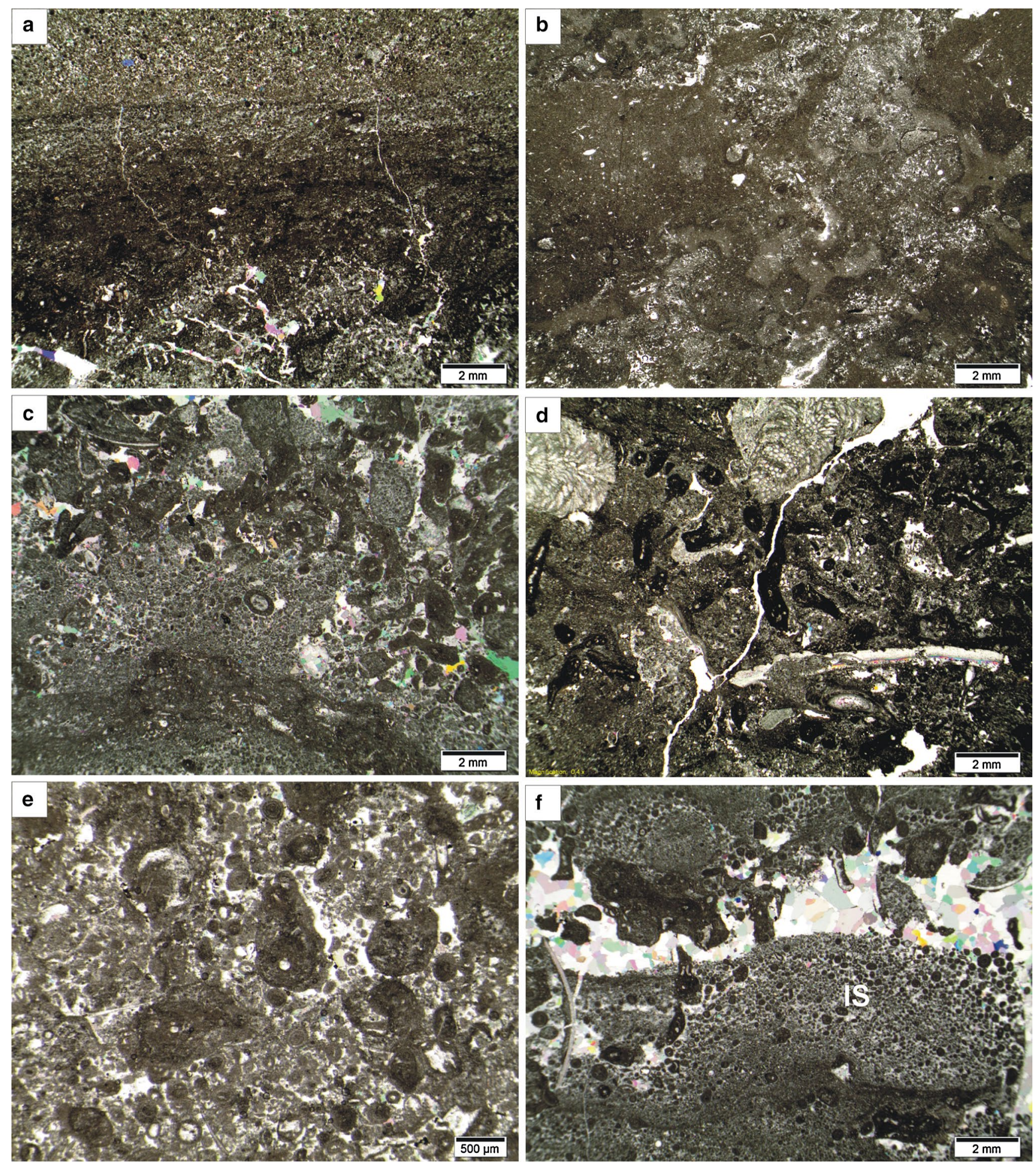

Fig. 6 Microfacies from Upper Jurassic deposits (FT 1-2). a Microbial sponge boundstone (FT 1). In the lower part of the photo, siliceous sponge with microbialites are visible. In the upper part, peloidal wackestone is present. 21P/2 well, depth $163.7 \mathrm{~m}$. b Microbial sponge boundstone with thrombolite. 21P well, depth $241.8 \mathrm{~m}$. c Microbial boundstone, which passes upward into the microbial-Crescentiella boundstone. 116 well, depth $188.0 \mathrm{~m}$. d Microbial-Cres-

centiella boundstone with numerous bryozoans. 21P/2 well, depth $120.2 \mathrm{~m}$. e Microbial-Crescentiella packstone with coated grains. 116 well, depth $196.0 \mathrm{~m}$. f Stromatactis-like cavity within microbialCrescentiella limestone. Lower part of cavity is filled with internal sediment (IS), whereas the upper part is filled with blocky cement. In the lower part of internal sediment, microbial crusts are visible. 21P/2 well, depth $143.6 \mathrm{~m}$ 

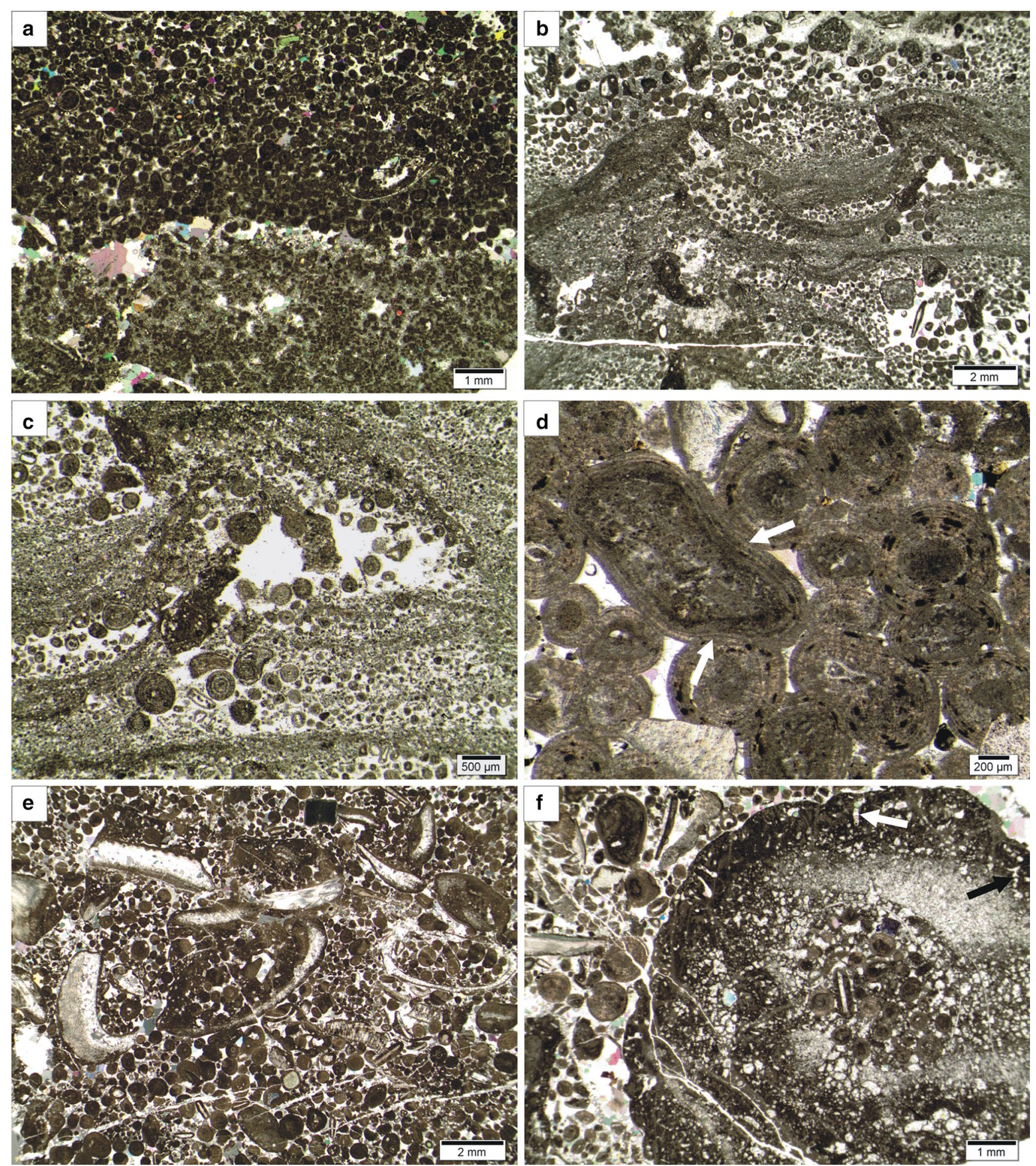

Fig. 7 Microfacies from Upper Jurassic deposits (FT 3). a Peloid packstone, which passes upward into the micritic-fine ooid-peloid packstone/grainstone. 124 well, depth $154.0 \mathrm{~m}$. b Micritic-fine-ooid grainstone-packstone with agglutinating stromatolite (central part of photo). 21P/2 well, depth $127.8 \mathrm{~m}$. c Ooid-bearing boundstone with ooids stabilized by microbial crusts. 21P/2, depth $127.8 \mathrm{~m}$. d Ooid

grainstone with compactional deformation (arrows) of the ooids. 124 well, depth $157.0 \mathrm{~m}$. e Ooid-bioclastic grainstone with numerous bivalve shells. 97 well, depth $312.5 \mathrm{~m}$. f Ooid-oncoid-bioclastic grainstone with Bacinella irregularis and Trogrotella incrustants (arrows). 124 well, depth $155.0 \mathrm{~m}$ 
form clusters. In their lower parts, cavities contain internal sediments, followed by calcite cement (Fig. 6f). The upper interfaces with the host sediment are irregular and follow the shapes of oncoids, ooids, Crescentiella and bivalve shells. In the last case, the roofs are smooth and convex downward. Internal sediment is grainstone with ooids up to $0.5 \mathrm{~mm}$ across and single oncoids, Crescentiella and bioclasts. Macroscopically, it is difficult to identify the boundaries between the internal sediment and the host sediment. Under the microscope, the boundaries are often the microbial crusts (Figs. 6f, 7b, c). In such cases, the internal sediment is a light-colored grainstone containing darker microbial crusts and the boundaries are somewhat wavy. In some cavities, the internal sediment is a grainstone grading into enclosing packstone.

Two types of calcite cement are present. The walls of cavities are covered with isopachous cement, up to $0.03 \mathrm{~mm}$ thick, whereas the central parts are filled with blocky cement of crystals up to $1.2 \mathrm{~mm}$. Within such blocky cements are oncoids, ooids, bioclasts, and irregular fragments of sediment composed of particles of enclosing rock (Fig. 6f).

The oolitic grainstone comprises aggregate grains, less commonly bioclasts and peloids. Dominating components are radial ooids with thin-laminated, fine-radial cortices, up to $1 \mathrm{~mm}$ across. Compactional deformation of ooids (Fig. 7d) and aggregate grains has taken place locally.

The oolitic-oncolitic-bioclastic grainstone contains numerous bivalve shells, echinoderms, gastropods, Crescentiella and aggregate grains (Fig. 7e). Moreover, oncoids also occur, with the microproblematica ulvophycean green alga Bacinella irregularis Radoičić 1959 (Schlagintweit et al. 2010) and characteristic, boring foraminifera Troglotella incrustans (Fig. 7f).

Facies interpretation The FT 3 microfacies represents the succession from fore shoal through shoal to back shoal of an oolitic-dominated inner-ramp setting, in which nonskeletal components prevailed (e.g., Bádenas and Aurell 2010). The oolitic grainstone is interpreted as normalmarine shallow water within the range of normal wave base (e.g., Flügel 2004). The oolitic-bioclastic grainstone was deposited in a moderate- to low-energy back-shoal or lagoonal environment. The presence of Bacinella irregularis Radoičić, 1959 suggests a shallow, subtidal, back-shoal environment. The Bacinella oncoids are genetically linked to low-energy, oligotrophic interior lagoons (e.g., Dupraz and Strasser 1999; Védrine et al. 2007; Bádenas and Aurell 2010), although, in the Złoczew area, these occur in a higher-energy back shoal with ooid-dominated grainstone.

The sedimentary environment of agglutinated stromatolites with numerous ooids and stromatactis-like and stromatactoid cavities was the slope on which ooids were temporarily deposited. The origin of stromatactis cavities, in general, is still controversial despite numerous investigations (see for review and references, e.g., Matyszkiewicz 1997a; Hladil et al. 2007; Aubrecht et al. 2009; Lazăr et al. 2011). Stromatactis-like cavities and stromatactoid cavities described in this paper differ from true stromatactis in terms of size, shape, and occurrence. The origin of the cavities here is related to remodeling of initial open spaces in an inhomogeneous, partly lithified sediment (cf. Matyszkiewicz 1997a; Neuweiler et al. 2001; Olchowy 2011). Such open spaces might have formed at the contacts of loose particles (ooids, oncoids, bioclasts, or intraclasts) and partly lithified microbial crusts during sedimentation (cf. Hladil et al. 2006). According to Schmid et al. (2001), the presence of small-scale discontinuities within sediment together with an unstable shelf position may led to gravitational slumping. The factor disturbing the stability of sediment with initial open spaces might have been synsedimentary tectonics responsible for generation of stress within the rocks (Matyszkiewicz 1997a; Olchowy 2011).

\section{FT 4: Gravity flow deposits}

This facies type is represented by debrites and calciturbidites. In the Złoczew Graben, the FT 4 sediments are observed only in narrow zones close to faults where they grade vertically and horizontally into FT 5 (Fig. 2). Debrites reach a thickness up to $15 \mathrm{~m}$ (Fig. 2). The boundaries between gravity-flow deposits and overlying (FT 5) and underlying sediments are distinct and their basal surfaces are erosional. The sediments are poorly sorted, have a variable clast size, a chaotic clast fabric, and a lack of stratification. The clasts are angular or subangular, polymictic, randomly distributed, and include: microbial-Crescentiella boundstone (FT 2), microbial-sponge boundstone, bioclastic wackestone-packstone (FT 1), lime mudstone (FT 5), and less commonly micritic-oolitic grainstone-packstone (FT 3) (Table 1). Clasts have created umbrella cavities with geopetal sediment below. The size of clasts varies from several $\mathrm{mm}$ to more than $10 \mathrm{~cm}$. The matrix between the clasts usually comprises Upper Jurassic rudstone-grainstone, packstone-wackestone, mudstone, and blocky cement (Figs. 5c, 8a). Upwards, breccias grade into calciturbidites with Bouma-type divisions $\mathrm{T}_{\mathrm{A}}$ to $\mathrm{T}_{\mathrm{E}}$, excluding convolute lamination (Figs. 5d, 8a, b).

Facies interpretation The FT 4 represents debrites and calciturbidites (e.g., Flügel 2004). The presence of debrites in narrow zones following the boundaries of the Złoczew Graben indicates synsedimentary tectonic activity along steep, tectonically controlled scarps (e.g., Drzewiecki and Simó 2002). Such sediments could not be transported for long distances due to the lack of buoyancy (e.g., Drzewiecki and Simó 2002). Tectonic activity in the graben was the main trigger for the sediment-gravity flows (e.g., 

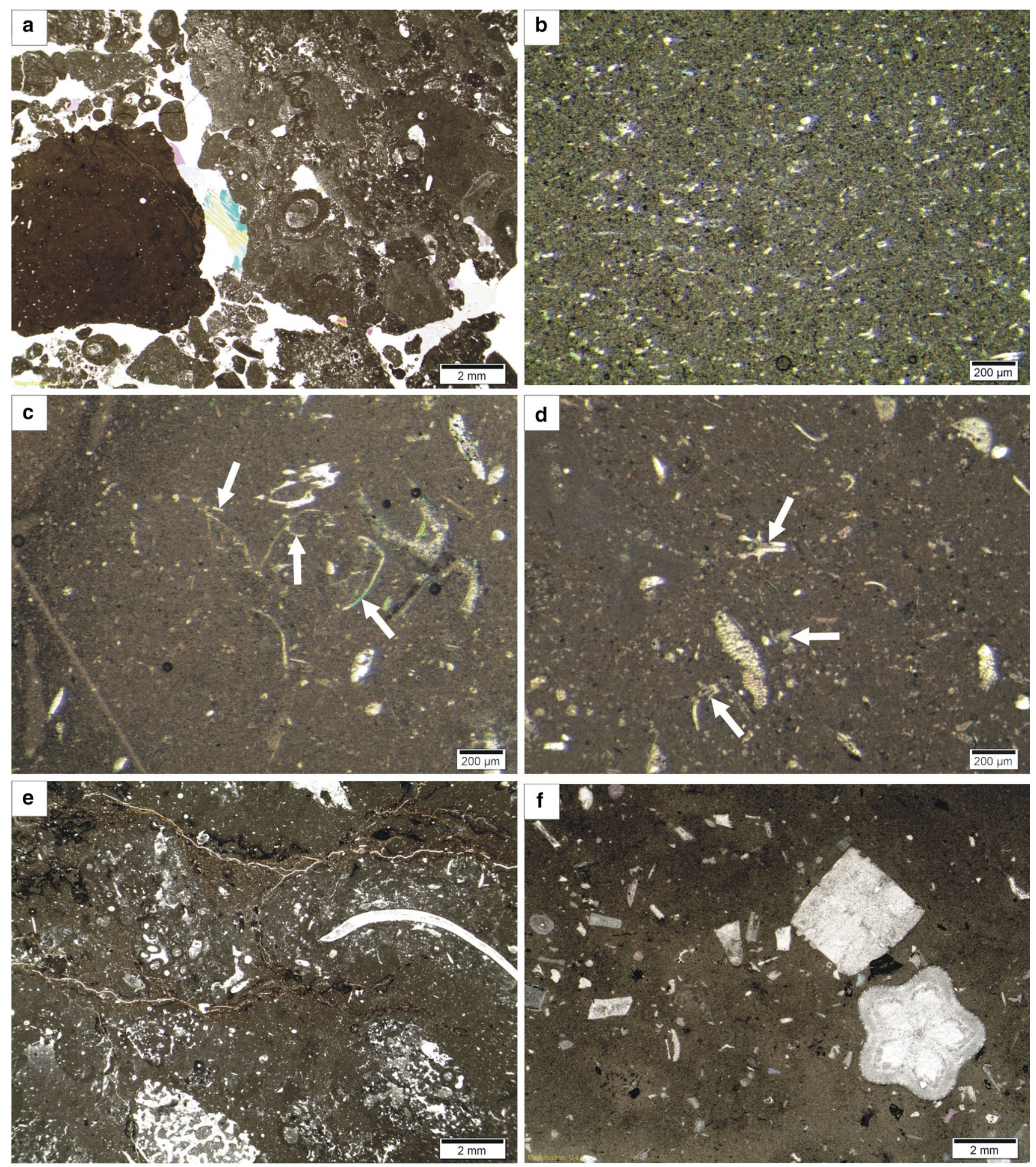

Fig. 8 Microfacies from the Upper Jurassic deposits (FT 4-6). a Rudstone with angular clasts. In the left part of the photo, a clast composed of mudstone/wackestone is present. In the right part of the photo, a clast composed of microbial boundstone with Terebella lapilloides. Lower part of Bouma division $\left(T_{\mathrm{A}}\right)$. 17GI well, depth $112.0 \mathrm{~m}$. b Fine bioclastic wackestone. Upper part with Bouma divi-

sions. 17GI well, depth 114.0 m. c, d Fine bioclastic wackestone with numerous planktonic remains of Saccocoma secundibranchials (arrows). 64 well, c depth $333.0 \mathrm{~m}$, d depth $332.5 \mathrm{~m}$. e Marly oncoid bivalve floatstone. $21 \mathrm{P}$ well, depth $251.8 \mathrm{~m}$. f Marl with fragments of benthic crinoids. 53 well, depth $307.0 \mathrm{~m}$ 
Matyszkiewicz 1996; Montenat et al. 2007; Krajewski et al. 2014).

\section{FT 5: Fine-grained detrital limestone and lime mudstone}

FT 5 was found in both the basement and the margins of the Złoczew Graben (Fig. 2). Its thickness does not exceed several meters and reaches a maximum in the marginal parts of the graben (Figs. 2, 3). FT 5 rests upon FT 1 in the basement of the graben and upon FT 2 and 3 along its margins. Up the sequence, FT 5 most commonly grades into marly limestone and marl of the FT 6 facies, in some cases forming limestone-marl alternations with a total thickness up to $40 \mathrm{~m}$. The FT 5 sediments are usually fine-bioclastic wackestone-packstone and mudstone (Table 1; Fig. 8c, d). The latter contain trace fossils including Thalassinoides and Chondrites. The FT 5 facies comprises common fragments of planktonic rovecrinoids Saccocoma sp., echinoids, spicules, benthic crinoids, filaments, and some fragments of siliceous sponges.

Facies interpretation The FT 5 sediments were deposited in an outer ramp setting (e.g., RMF 3-5; Flügel 2004). The transition from mid-inner ramp facies to outer-ramp facies indicates the essential change in sedimentary conditions related to submergence of the carbonate platform.

\section{FT 6: Marly limestone and marl}

This facies variety occurs above the FT 5 facies (Figs. 2, 3 ). It commonly forms limestone-marl alternations with FT 5 sediments, with rare clay intercalations up to several centimeters thick. Thickness of FT 6 may reach $10 \mathrm{~m}$, but usually it does not exceed several meters. The FT 6 sediments are grey, thin-bedded, bioturbated marl and marly limestone, locally with abundant fragments of ammonites, bivalves, crinoids, and oncoids (the latter found in the lowermost part of the FT 6 succession). The marly microfacies comprises: (1) oncolitic-bivalve wackestone-floatstone, (2) mudstone, and (3) bioclastic wackestone-packstone (Table 1). Contents of $\mathrm{CaCO}_{3}$ change from 45 to $98 \mathrm{wt} \%$.

Oncolitic-bivalve wackestone-floatstone occurs in the lowermost parts of the FT 6 section, as beds in marly limestone up to $10 \mathrm{~cm}$ thick. Oncoids vary in size from a few $\mathrm{mm}$ to $3 \mathrm{~cm}$. Both oval and irregular oncoids with sharp or diffused contours are present. Most oncoids have a bioclastic nucleus (Fig. 8e). Cortexes consist of micrite or, rarely, of organism-bearing lamination. Some oncoids reveal traces of bioerosion.

In marl and marly limestone, numerous trace fossils are common, represented by Planolites and Chondrites. In bioclastic wackestone-packstone, crinoids are common, particularly the remains of benthic Isocrinus sp. and large, abraded pluricolumnals of Millercrinidae
(Fig. 8f) (Gorzelak and Salamon 2009), as well as poorly preserved, planktonic Roveacrinidae (Saccocoma sp.) (Fig. 8c, d). Fragments of echinoids, foraminifers and filaments also occur. Skeletal elements of crinoids are commonly arranged parallel to each other (Fig. 5f). The sediments contain a moderately preserved but taxonomically poor nannoplankton assemblage dominated by long-lived Watznaueria and Cyclagelosphaera (Upper Jurassic-Lower Cretaceous) among which were identified Watznaueria barnesae (Black) Perch-Nielsen, small Watznaueria britannica (Stradner) Reinhardt, Cyclagelosphaera margerelii Noe. and Etthmorhabdus sp.

Facies interpretation Bioturbated marl and marly limestone represent the deepest facies identified, deposited in a low-energy, outer-ramp setting. Marly facies with oncoids were described from low-energy, mixed, carbonate-siliciclastic mid-ramp setting (e.g., Olivier et al. 2011). The appearance of oncoids in marly sediments along with the traces of bioerosion on their surfaces indicate nutrient-rich and turbid waters. Relatively well-preserved crinoid fragments without clear signs of abrasion indicate short postmortal transport (Gorzelak and Salamon 2013). Although the parallel arrangement of their skeletons imply transport over some distance, a lack of microencrustations on the crinoid surfaces suggests rapid burial (e.g., Brett et al. 1997; Salamon and Gorzelak 2010). Crinoids settled in deep water (about 200-250 m depths) beneath the storm wave base, under low-energy conditions, and at low sedimentation rates.

Small specimens of Watznueria britannica indicate mesotrophic to eutrophic conditions (e.g., Pittet and Mattioli 2002; Olivier et al. 2004). Their common occurrence together with the low-diversity nannoplankton assemblage may be related to higher trophic conditions and a stratified water column. The more common occurrence of Watznueria barnesiae points out to somewhat better-oxygenated but still highly trophic conditions.

\section{Discussion}

\section{Facies development}

The dense grid of exploration wells together with the facies analysis enabled the determination of spatial relationships of facies in the Złoczew Graben (Figs. 2, 3). Facies relations observed across faults separating the marginal hanging-wall blocks from the down-thrown central part of the graben indicate synsedimentary movements during the Late Jurassic stage of its evolution. A rapid vertical facies change observed in all sections distributed across the graben and the bounding shoulders occurs between FT 1-3 and FT 4-6 (Figs. 2, 3). This 
boundary documents an important depositional change and is used as datum in correlation of the lithological columns shown in Figs. 2 and 3. Based on the analysis of archival and new data on facies relationships, two developmental stages in the depositional system were identified: Upper Oxfordian (sensu Bifurcatus-Planula zones sequence) and Lowermost Kimmeridgian (sensu Platynota zone) (Fig. 4).

\section{Upper Oxfordian stage}

The sedimentary succession in the Złoczew area begins with the microbial-sponge facies (FT 1). Several transitions of FT 1 and FT 2-3 (Figs. 2, 4) probably correspond to cyclic sea-level changes. The regressive trends during the Late Oxfordian are visible at the end of the Bifurcatus and Planula zones (e.g., Hardenbol et al. 1998). Hence, the oldest sediments encountered in this research may represent the Bifurcatus zone.

FT 1 represents typical Upper Oxfordian facies, widely distributed in Europe (e.g., Aurell et al. 1995; Leinfelder et al. 1996; Matyszkiewicz 1997b; Olóriz et al. 2003; Olivier et al. 2004, 2011; Reolid et al. 2005). The development of FT 1 can be related to a more distal mid-ramp setting. Such sediments represent matrix-supported and skeleton-supported, microbial-sponge reefs (sensu Riding 2002) and contemporaneous bedded limestone deposited in inter-reef depressions. The microbial-sponge reef facies were found mostly in hanging-wall blocks of the Złoczew Graben whereas at the graben center the equivalent thinbedded facies were deposited with small, meter-scale sponge bioherms interbedded with marly limestone. Thus, it can be suggested that the course of the Złoczew Graben followed the morphology of the sea floor during the Late Oxfordian (Fig. 2).

FT 1 was gradually replaced by microbial-Crescentielladominated FT 2. Development of these facies in the study area is referred to the regressive trend in the Late Oxfordian (Planula Zone; Matyszkiewicz and Felisiak 1992; Matyszkiewicz 1997b; Krajewski et al. 2011a) (Fig. 4). In successions with FT 2, a distinct decrease in the number of sponges and thrombolites was recorded, and an increase in agglutinated stromatolites, coated grains, and detrital material. These sediments were not encountered in the central part of the graben, still occupied by FT 1 . The FT 2 sediments grade up into oolitic FT 3 (Fig. 2) to form a succession from mid-ramp microbial-Crescentiella reefs to shallow-water, inner-ramp oolitic fore-shoal, shoal, and back-shoal facies (cf. Bádenas and Aurell 2010). These sediments occur exclusively in the western and northwestern blocks of the graben (Fig. 2). Hence, it is suggested that during the Upper Oxfordian, the Złoczew area formed a transition area between the inner ramp extending northward and/or westward, and the mid ramp extending to the southeast and south.

\section{The Lowermost Kimmeridgian stage}

At the Oxfordian/Kimmeridgian boundary, an important change in sedimentary environment took place, from midinner carbonate ramp to mixed, carbonate-siliciclastic outer ramp (Figs. 2, 3, 4, 9c). The debrites and calciturbidites (FT 4) deposited in the marginal zone of the Złoczew Graben reflect its tectonic activity. This suggestion is supported by the presence of stromatactis-like cavities, which were interpreted as products of synsedimentary tectonic movements by Matyszkiewicz (1997a) and Olchowy (2011). Material laid down as the gravity flow deposits were derived mostly from areas of FT 1-3, whereas fine-grained calciturbidites were derived from FT 5. The lack of reef complexes well-marked in sea-floor relief along with the dominance of detrital deposition strongly limited the formation of steep slopes in the Late Oxfordian, along which redeposition could have taken place. However, steep slopes might have formed due to syndepositional faulting. Seismic activity and normal faulting at the horst/graben margin were the main triggers of gravity-flow deposits (e.g., Kutek 1994; Matyszkiewicz 1996; Montenat et al. 2007; Krajewski et al. 2014).

Both the FT 4 sediments in the graben and the FT 1-3 deposits along its margin grade upward and laterally into FT 5 and/or FT 6 facies (Figs. 2, 3). Such a transition from benthic to pelagic sedimentation documents the submergence of the ramp. This event can be observed in successions from the Kraków-Częstochowa and the Wieluń uplands as well as from the southwestern margin of the Holy Cross Mountains and from the Miechów Depression (e.g., Kutek 1994; Matyszkiewicz 1996; Matyja and Wierzbowski 2006; Złonkiewicz 2009; Krajewski et al. 2014). Initially, oncolitic-marly facies appeared, related to a more distal setting of the mid ramp (e.g., Olivier et al. 2011). These were followed by the marly-limestone alternations representing a deep-water, mixed carbonate-siliciclastic outer-ramp facies (Fig. 9c).

The results obtained in the area of the Złoczew High and those reported from the Kraków-Częstochowa Upland correspond well to successions described from the Lower Kimmeridgian ramp of western Europe (e.g., Bádenas and Aurell 2001, 2010; Olóriz et al. 2003; Olivier et al. 2008). Transition from carbonate ramp to mixed, carbonate-siliciclastic ramp systems observed in the Lower Kimmeridgian can be related to third-order sea-level oscillations and is indicated by the increasing content of terrigenous material (Fig. 4) (e.g., Olivier et al. 2008; Colombié et al. 2014), supplied as a result of tectonic activity close to the Oxfordian-Kimmeridgian boundary. 
Fig. 9 Upper Jurassic paleogeographical position and facies distribution on the Małopolska Block (central and southern Poland). a Paleogeographical position of the study areas (after Ziegler 1990, modified) with the position of main tectonic structures (in red): Małopolska Block (MB), Łysogóry Block (ŁB), Upper Silesian Block (USB). Red lines indicate main faults bordering the Małopolska Block: Holy Cross Fault (HCF) and Kraków-Lubliniec Fault (KLF), Chmielnik Fault (CHF). Abbreviations in black indicate areas with discussed Upper Jurassic deposits: Złoczew High (ZH), Bełchatów High (BH), SW margin Holy Cross Mt., (HCM), Lublin area (LA), Wieluń Upland (WU), Miechów Depression (MD) and Kraków-Częstochowa Upland (KCU). Yellow arrow indicates direction of progradation of oolitic platform suggested so far. Green arrow indicates direction of progradation of oolitic platform in the Złoczew High area suggested by the authors. $L H$ Lusatian High, $B M$ Bohemian Massif. b Schematic cross sections between KCU-HCM, KCU-BH, and KCU-ZH showing distribution of Upper Oxfordian (Planula Zone) facies on the main tectonic blocks in the basement. On the SW marginal parts of the tectonic blocks, microbial-Crescentiella, coral, and oolitic facies were deposited. In the central part of the MB, microbial-sponge facies were deposited. I-cross section between KCU a HCM oriented transversally to the MB. Yellow arrow indicates direction of shallow-water platform progradation suggested so far. II-cross section between KCU and BH oblique to the MB. Green arrow indicates direction of shallow-water platform progradation. III-cross section between $\mathrm{KCU}$ and $\mathrm{ZH}$ oblique to the MB. Green arrow indicates direction of shallow-water platform progradation suggested by the authors. c Cross section oriented transversally to the MB, which shows distribution of deep-water outer platform lime mudstone and marly facies on the MB during the Lowermost Kimmeridgian (Platynota Zone). On the tectonically active edges of the $\mathrm{MB}$, gravity-flow deposits were deposited

\section{Regional implications}

It is widely accepted in the Polish literature (e.g., Matyja et al. 1989; Gutowski et al. 2005 and references therein) that in the Upper Oxfordian the Złoczew High, KrakówCzęstochowa and Wieluń uplands belonged to a southward-sloping, deep-water open shelf occupied by a sponge megafacies. This megafacies developed on the foreland of a shallow-water carbonate platform prograding from the east, from the Lublin area (Fig. 9a, b). In the Planula Zone, the platform front reached the southwestern margin of the Holy Cross Mountains (e.g., Matyja et al. 1989; Gutowski et al. 2005) where shallow-water, oolitic facies graded through coral facies to deep-water sponge facies. The argument in favor of deep-water, open-shelf deposition west and south from the Holy Cross Mountains was the development of Upper Oxfordian strata as lime mudstone and sponge facies described from both the Miechów Depression and the Wieluń Upland (e.g., Deczkowski 1977; Kutek et al. 1977; Wierzbowski et al. 1983; Złonkiewicz 2009). In accordance with the ramp model, facies encountered southwest from these areas, in the Kraków-Częstochowa Upland, should occupy more distal and deeper-water settings. However, sediments known from the southern part of the KrakówCzęstochowa Upland, dominated by microbial-Crescentiella facies with numerous coated grains, are similar to

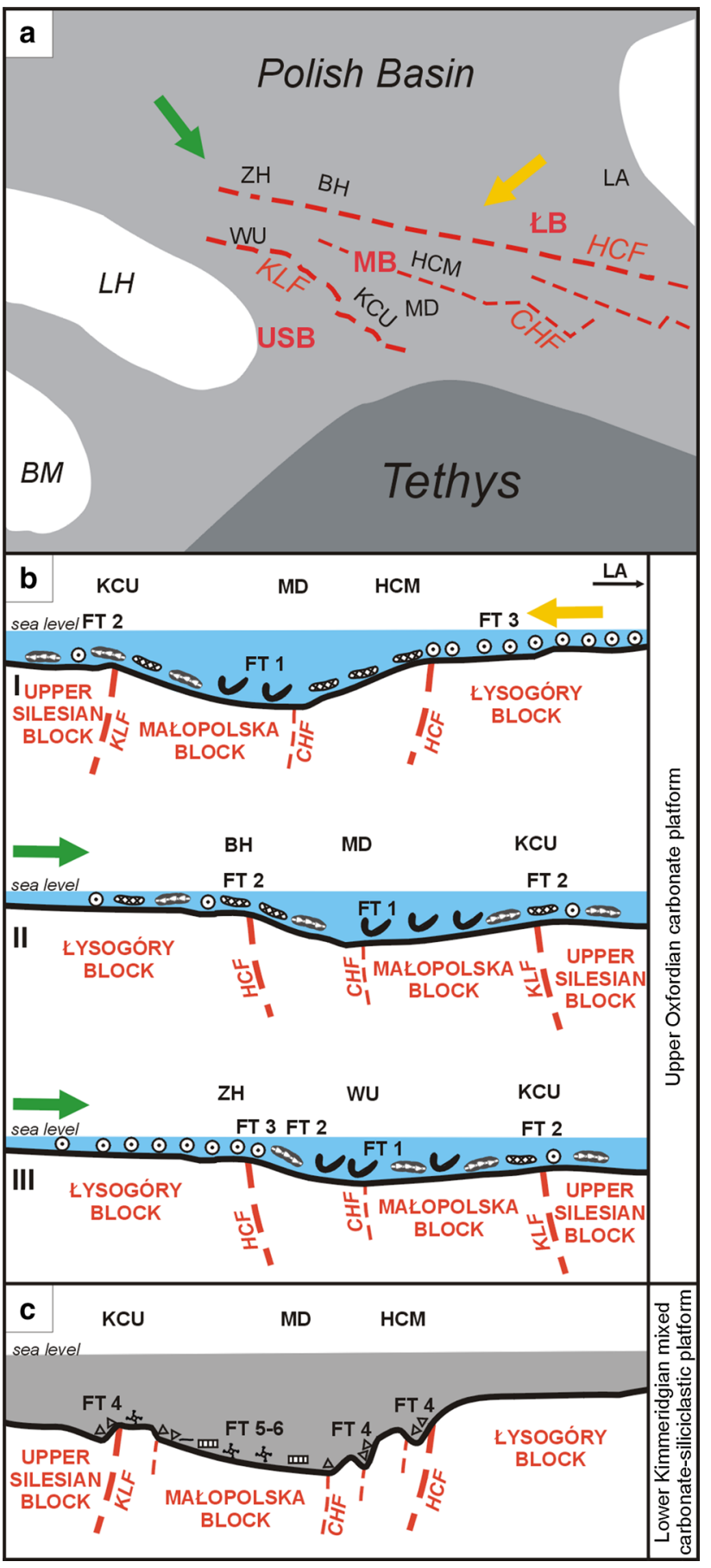

those from the Złoczew area (e.g., Matyszkiewicz and Felisiak 1992; Krajewski 2000; Matyszkiewicz et al. 2006a). Such facies are typical of more shallow-water settings within the ramp, which is in obvious contradiction to theoretically shallower successions of the Miechów Depression and the Wielun Upland (Fig. 9b). The problem of ramp system interpretation has been already discussed by Matyszkiewicz (1997b) who based his opinion on the more shallow-water character of Upper Oxfordian facies seen 
in the southern part of the Kraków-Częstochowa Upland, in comparison with those described from areas located in the north. The sedimentological features together with the tectonic controls (Kutek 1994) led to the interpretation of the southern part of the Kraków-Częstochowa Upland as an elevation of the shelf margin (Matyszkiewicz 1997b). In the following years, the origin of this elevation was linked to a structure in the Paleozoic basement (Matyszkiewicz et al. 2006a, b).

The sedimentary successions described from the Złoczew area document a continuous facies transition from mid-ramp, microbial-sponge through microbialCrescentiella to inner-ramp oolitic facies but without the coral-dominated facies, as in the southwestern margin of the Holy Cross Mountains. It is suggested that in the Złoczew area as well as in the southern part of the KrakówCzęstochowa Upland the equivalents of coral facies are the microbial-Crescentiella (FT 2) facies deposited in a midramp setting. Indirect support of this concept is provided by the results of studies on Upper Oxfordian coral facies from central and southern Poland (Roniewicz and Roniewicz 1971; Roniewicz 2004), where coral facies are dominated by platy coral colonies of Microsolena, which grew in a mid-ramp, low-light and low-energy setting, below fair-weather wave base (Insalaco 1996; Leinfelder et al. 1996; Olivier et al. 2011). Corals described from the sites in the Kraków-Częstochowa Upland most commonly occur together with the Crescentiella-dominated facies (e.g., Olchowy 2011).

An important aspect of Upper Oxfordian facies distribution in central and southern Poland is the earlier appearance of oolitic facies in the Zloczew area, in comparison with the areas where, according to recent interpretations, more shallow-water settings were developed. In fact, the oolitic facies corresponding to the inner-ramp shoal and backshoal environments appeared in the Złoczew area as early as at the end of the Oxfordian. Considering the interpretation of Złoczew area, the accepted model of open-shelf deposition and progradation of the shallow-water platform from the Lublin area (Fig. 9a, b) needs further consideration. During the Planula Zone, the progradation of shallowwater oolitic facies might have proceeded not only from the east (from the Lublin area) but also from the north-west, from the Złoczew High (cf. Niemczycka and BrochwiczLewiński 1988) (Fig. 9a, b). During the Planula Zone, the Złoczew area was located in the marginal part of the inner ramp, prograding to the southeast and south.

The Late Oxfordian facies distribution in central and southern Poland reflects the trends of the main, transregional tectonic zones that border the Małopolska Block (Fig. 9b). In the Upper Oxfordian, at the margin of the main tectonic blocks (Fig. 9a, b), the microbial-Crescentiella, oolitic and coral facies were deposited in the areas of the
Złoczew and Bełchatów highs, and along the southwestern margin of the Holy Cross Mountains. On the other hand, in the southwest, in the central part of the Małopolska Block (Miechów Depression, Wieluń Upland), the deeper, microbial-sponge and lime mudstone facies were deposited (Fig. 9b). However, on the southwestern, uplifted margin of the Małopolska Block (recent area of the KrakówCzęstochowa Upland), the microbial-Crescentiella facies with numerous coated grains and rare corals was deposited (Fig. 9b). The uplifted, marginal parts of such blocks were occupied by shallow-water FT 2 and FT 3 locally accompanied by coral facies, whereas the deeper-water FT 1 and lime mudstone were widely distributed in the central part of the Małopolska Block (Fig. 9a, b).

One of the most important factors controlling sedimentation in the Złoczew area in the Late Jurassic, near the Planula/Platynota boundary, was synsedimentary tectonics, particularly intensive in the Platynota Zone (e.g., Matyszkiewicz 1996; Krajewski et al. 2014). Most probably, the Late Jurassic tectonic movements along the eastern margin of the West European Platform resulted in reactivation of the main dislocation zones cutting the tectonic blocks in the Paleozoic basement (Bednarek et al. 1985; Żaba 1999; Krzywiec 2006; Matyszkiewicz et al. 2006a; Gutowski and Koyi 2007; Buła and Habryn 2010, 2011; Krajewski et al. 2014) (Fig. 1). The synsedimentary tectonics active in this zone influenced the development of gravity-flow deposits. The Lowermost Kimmeridgian (Platynota Zone) gravityflow deposits (Fig. 9c) deposited along regional dislocations bounding the Małopolska Block are known from: (1) the southern Kraków-Częstochowa Upland (e.g., Kutek 1994; Matyszkiewicz 1996, 1997a, b), (2) the southwestern margin of the Holy Cross Mountains (e.g., Migaszewski et al. 2006; Krajewski et al. 2014), (3) the Ukrainian part of the Carpathian Foredeep overprinting the Małopolska Block (Krajewski et al. 2011b) and (4) the Łódź Depression (Krajewski et al. 2014) (Fig. 1a).

The best analogue of the Złoczew Graben is the Krzeszowice Graben located at the southwestern margin of the Małopolska Block (Fig. 1). The most important similarities of the Złoczew and the Krzeszowice grabens are: (1) their structural position along the marginal part of the Małopolska Block which was tectonically active in the Mesozoic (Fig. 1a), (2) the similar thickness of Oxfordian sediments (cf. Matyszkiewicz et al. 2012), (3) the stratigraphic position (cf. Matyszkiewicz 1996; Ziółkowski 2007), (4) the transition from benthic to planktonic sedimentation at the boundary of the Planula and Platynota zones and (Matyszkiewicz 1996; Krajewski et al. 2014) (5) the presence of calciturbidites and debrites in the marginal parts of both grabens (e.g., Matyszkiewicz 1996; Krajewski et al. 2014). Other examples are the Kleszczów Graben in which Lower Kimmeridgian, synsedimentary gravity-flow deposits 
with calciturbidites and pelagic sediments (Fig. 5d) were observed along the margins (e.g., Krajewski et al. 2014) as well as Wolbrom Graben (Fig. 1a) (Bednarek et al. 1985; Matyszkiewicz et al. 2006a). These examples demonstrate that the facies development of the ramp system in the Polish part of the peri-Tethys shelf was periodically strongly modified by synsedimentary tectonics active in the marginal parts of trans-regional tectonic blocks developed in the eastern part of the West European Platform, particularly along the margins of the Małopolska Block.

The intensive development of gravity-flow deposits in the Lower Kimmeridgian and the change of deposition towards the clay-rich environment in the Małopolska Block (Fig. 9c) correspond well to the features of Lower Kimmeridgian ramp systems described in western Europe (e.g., Bádenas and Aurell 2001, 2010; Olivier et al. 2008) where such changes were related to both North Atlantic and west European tectonics.

\section{Conclusions}

1. Upper Oxfordian-Lower Kimmeridgian sediments from the Złoczew Graben include six facies types. The mid-ramp facies comprises microbial-sponge and microbial-Crescentiella limestone; the inner-ramp facies includes oolitic-bioclastic limestone; the outerramp facies has fine-grained, detrital limestone, lime mudstone, marly limestone, and marl. The Planula/ Platynota boundary in the Złoczew Graben area shows a transition from shallow-water, inner-ramp facies to deep-water, outer-ramp facies with simultaneous development of gravity-flow deposits, calciturbidites, and debrites.

2. The presence of calciturbidites and debrites in the marginal zone of the Złoczew Graben reflects Late Jurassic activity of boundary faults of the graben.

3. The transition from inner- and mid-ramp facies to mixed, carbonate-siliciclastic outer-ramp facies resulted from tectonic movements of the Małopolska Block, from increasing supply of siliciclastic material and from the sea-level rise in the Early Kimmeridgian (Platynota zone).

4. The selected facies types and their distribution visualized in a 3D model of the Złoczew Graben enabled a reconstruction of the facies architecture during the Late Jurassic stage of graben evolution. The Złoczew Graben can be presented as a model of similar grabens cutting through the Upper Jurassic formations in central and southern Poland, in the marginal zone of the Małopolska Block.

5. Sedimentation in the Polish part of the peri-Tethys ramp system characterized by the sea-level rise and transition from mid-inner carbonate ramp to outer, mixed, carbonate-siliciclastic ramp at the Planula/Platynota boundary corresponds well to the Lowermost Kimmeridgian ramp system known from elsewhere in western Europe.

Acknowledgments The authors are very much indebted to the staff of the Bełchatów Lignite Mine, who kindly provided materials and documentation from wells and gave permission for the publication of them. The authors are grateful to the two reviewers, R. Aubrecht and M. Salamon, and to the editor M. Tucker and M. Wendorff for their constructive comments and suggestions that considerably improved this paper. We would like to thank B. Olszewska and M. Garecka for the help in identification of some microfossils. The research was financed from the AGH-UST Grant No. 11.11.140.626.

Open Access This article is distributed under the terms of the Creative Commons Attribution 4.0 International License (http://creativecommons.org/licenses/by/4.0/), which permits unrestricted use, distribution, and reproduction in any medium, provided you give appropriate credit to the original author(s) and the source, provide a link to the Creative Commons license, and indicate if changes were made.

\section{References}

Aubrecht R, Schlögl J, Krobicki M, Wierzbowski H, Matyja BA, Wierzbowski A (2009) Middle Jurassic stromatactis mudmounds in the Pieniny Klippen Belt (Carpathians) - a possible clue to the origin of stromatactis. Sediment Geol 213:97-213

Aurell M, Bosence D, Waltham DA (1995) Carbonate ramp depositional systems from a Late Jurassic epeiric platform (Iberian basin, Spain): a combined computer modelling and outcrop analysis. Sedimentology 42:75-94

Bádenas B, Aurell M (2001) Kimmeridgian palaeogeography and basin evolution of northeastern Iberia. Palaeogeogr Palaeoclimatol Palaeoecol 168:291-310

Bádenas B, Aurell M (2010) Facies models of a shallow-water carbonate ramp based on distribution of non-skeletal grains (Kimmeridgian, Spain). Facies 56:89-110

Bednarek J, Górecka E, Zapaśnik T (1985) Tectonically controlled development of ore mineralization in Jurassic sequence of the Silesian-Cracovian Monocline. Ann Soc Geol Polon 53:43-62 (in Polish with English summary)

Borowicz A, Frankowski R, Gądek A, Jończyk W, Specylak- Skrzypecka J, Ślusarczyk G (2007) Złoże węgla brunatnego "Złoczew"-Budowa geologiczna, zasoby i perspektywy eksploatacji. Górnictwo i Geoinżynieria 31:141-150 (in Polish)

Brett CE, Moffat HA, Taylor WL (1997) Echinoderm taphonomy, taphofacies, and Lagerstatten. Paleontol Soc Pap 3:147-190

Buła Z, Habryn R (2010) Precambrian and Paleozoic geology of Cracow region. In: Jachowicz-Zdanowska M, Buła Z (eds) Prekambr i Paleozoik region krakowskiego-model budowy geologicznej-jego aspekt utylitarny. Państw Inst Geol, Warszawa, pp 7-39 (in Polish and English)

Buła Z, Habryn R (2011) Precambrian and Paleozoic basement of the Carpathian Foredeep and the adjacent Outer Carpathians (SE Poland and West Ukraine). Ann Soc Geol Polon 81:221-239

Chatalov A, Bonev N, Ivanova D (2015) Depositional characteristics and constraints on the mid-Valanginian demise of a carbonate platform in the intra-Tethyan domain, Circum-Rhodope Belt, northern Greece. Cretac Res 55:84-115 
Colombié C, Giraud F, Schnyder J, Götz AE, Boussaha M, Aurell M, Bádenas B (2014) Timing of sea level, tectonics and climate events during the uppermost Oxfordian (Planula zone) on the Iberian ramp (northeast Spain). Palaeogeogr Palaeoclimatol Palaeoecol 412:17-31

Deczkowski Z (1977) Geology of the Permo-Mesozoic cover and its basement in the Eastern part of the Fore-Sudetic Monocline (Kalisz-Częstochowa area). Prace Inst Geol 82:1-63 (in Polish with English Summary)

Deczkowski Z, Gajewska I (1983) Geological structure of basement of the Tertiary in the Złoczew and Gostyń troughs (Fore-Sudetic Monocline). Geol Q 27:535-546 (in Polish with English summary)

Drzewiecki PA, Simó JA (2002) Depositional processes, triggering mechanisms and sediment composition of carbonate gravity flow deposits: examples from the Late Cretaceous of the south-central Pyrenees, Spain. Sediment Geol 146:155-189

Dukacz P (2013) Geological structure of the central part of the Złoczew Graben. Unpublished M.Sc. Thesis, AGH University of Science and Technology, Sosnowiec, Kraków

Dupraz C, Strasser A (1999) Microbialites and microencrusters in shallow coral bioherms (Middle to Late Oxfordian, Swiss Jura Mountains). Facies 40:101-130

Flügel E (2004) Microfacies of carbonate rocks: analysis, interpretation and application. Springer, Berlin, p 976

Golonka J (2004) Plate tectonic evolution of the southern margin of Eurasia in the Mesozoic and Cenozoic. Tectonophysics 381:235-273

Gorzelak P, Salamon MA (2009) Signs of benthic predation on Late Jurassic stalked crinoids, preliminary data. Palaios 24:70-73

Gorzelak P, Salamon MA (2013) Experimental tumbling of echinoderms - taphonomic patterns and implications. Palaeogeogr Palaeoclimatol Palaeoecol 386:569-574

Gutowski J, Koyi H (2007) Influence of oblique basement strike-slip faults on the Mesozoic evolution of the south-eastern segment of the Mid-Polish Trough. Basin Res 19:67-86

Gutowski J, Popadyuk IV, Olszewska B (2005) Late Jurassic-earliest Cretaceous evolution of the epicontinental sedimentary basin of southeastern Poland and Western Ukraine. Geol Q 49:31-44

Hardenbol J, Thierry J, Farley MB, Jacquin T, de Graciansky PC, Vail PR (1998) Jurassic chronostratigraphy. In: de Graciansky PC, Hardenbol J, Jacquin T, Vail PR (eds) Mesozoic and Cenozoic sequence stratigraphy of European basin. SEPM Spec Pub, 60

Hladil J, Růžička M, Koptíková L (2006) Stromatactis cavities in sediments and the role of coarse-grained accessories. Bull Geosci 81:123-146

Hladil J, Koptíková L, Růžička M, Kulaviak L (2007) Experimental effects of surfactants on the production of stromatactis-shaped cavities in artificial carbonate sediments. Bull Geosci 82:37-50

Insalaco E (1996) Upper Jurassic microsolenid biostromes of northern and central Europe: facies and depositional environment. Palaeogeogr Palaeoclimatol Palaeoecol 121:169-194

Kaya MY, Altiner D (2014) Terebella lapilloides Munster, 1833 from the Upper Jurassic-Lower Cretaceous Inalti carbonates, northern Turkey: its taxonomic position and paleoenvironmental-paleoecological significance. Turk J Earth Sci 23:166-183

Kaya MY, Altiner D (2015) Microencrusters from the Upper JurassicLower Cretaceous İnaltı Formation (Central Pontides, Turkey): remarks on the development of reefal/peri-reefal facies. Facies $61: 18$

Keupp H, Koch R, Leinfelder R (1990) Steuerungsprozesse der Entwicklung von Oberjura-Spongiolithen, Süddeutschlands: Kenntnisstand, Probleme und Perspektiven. Facies 23:141-174

Keupp H, Jenisch A, Herrmann R, Neuweiler F, Reitner J (1993) Microbial carbonate crust: a key to the environmental analysis of fossil spongiolites? Facies 29:41-54
Krajewski M (2000) Lithology and morphology of Upper Jurassic carbonate buildups in the Będkowska Valley, Kraków region, Southern Poland. Ann Soc Geol Polon 70:51-163

Krajewski M (2008) Lithology of the Upper Jurassic-Lower Cretaceous (Tithonian-Lower Berriasian) Ay-Petri reef complex (southern Ukraine, the Crimea Mountains). N Jb Geol Paläont Abh 249:239-255

Krajewski M, Olszewska B (2006) New data about microfacies and stratigraphy of the Late Jurassic Aj-Petri carbonate buildup (SW Crimea Mountains, S Ukraine). N Jb Geol Paläont Mon 5:298-312

Krajewski M, Matyszkiewicz J, Król K, Olszewska B (2011a) Facies of the Upper Jurassic-Lower Cretaceous deposits from the southern part of the Carpathian Foredeep basement in the Kraków-Rzeszów area (southern Poland). Ann Soc Geol Polon 81:269-290

Krajewski M, Król K, Olszewska B, Felisiak I, Skwarczek M (2011b) Facies of the Upper Jurassic-Lower Cretaceous sediments in the basement of the Carpathian Foredeep (western Ukraine). Ann Soc Geol Polon 81:291-307

Krajewski M, Olchowy P, Felisiak I (2014) Lower Kimmeridgian layer with bored and encrusted hiatus concretions (Upper Jurassic, Central Poland): implications for stratigraphy and basin evolution. Ann Soc Geol Polon 84:113-129

Krzywiec P (2006) Triassic-Jurassic evolution of the Pomeranian segment of the Mid-Polish Trough-basement tectonics and subsidence patterns. Geol Q 50:139-150

Kutek J (1994) Jurassic tectonic events in south-eastern Poland. Acta Geol Polon 44:167-221

Kutek J, Wierzbowski A, Bednarek J, Matyja BA, Zapaśnik T (1977) Notes on the Upper Jurassic stratigraphy in the Polish Jura Chain. Prz Geol 25:238-445 (in Polish with English summary)

Lazăr I, Panaiotu CE, Grigore G, Sandy MR, Peckmann J (2011) An unusual brachiopod assemblage in a Late Jurassic (Kimmeridgian) stromatactis mud-mound of the Eastern Carpathians (Hăghimaş Mountains), Romania. Facies 57:627-647

Leinfelder RR, Werner W, Nose M, Schmid DU, Krautter M, Laternser R, Takacs M, Hartmann D (1996) Paleoecology, growth parameters and dynamics of coral, sponge and microbolite reefs from the Late Jurassic. Göttinger Arb Geol Paläont Sb 2:227-248

Matyja BA, Wierzbowski A (2006) Field trip B 2-Latosówka Quarry, basina to biohermal facies and synsedimentary mass movements; Upper Oxfordian, Planula Zone. In: Wierzbowski A et al. (eds) Jurassic of Poland and adjacent Slovakian Carpathians. Field trip guidebook. 7th International Congress on the Jurassic System, Kraków, Poland

Matyja BA, Gutowski J, Wierzbowski A (1989) The open shelfcarbonate platform succession at the Oxfordian/Kimmeridgian boundary in the SW margin of the Holy Cross Mts: stratigraphy, facies and ecological implications. Acta Geol Pol 39:29-48

Matyszkiewicz J (1996) The Significance of Saccocoma-calciturbidites for the analysis of the Polish Epicontinental Late Jurassic Basin: an example from the Southern Cracow-Wielun Upland (Poland). Facies 34:23-40

Matyszkiewicz J (1997a) Stromatactis cavities and stromatactis-like cavities in the Upper Jurassic carbonate buildups at Młynka and Zabierzów (Oxfordian, southern Poland). Ann Soc Geol Polon $67: 45-55$

Matyszkiewicz J (1997b) Microfacies, sedimentation and some aspects of diagenesis of Upper Jurassic sediments from the elevated part of the Northern peri-Tethyan shelf: a comparative study on the Lochen area (Schwäbische Alb) and the Cracow area (CracowWieluń Upland, Poland). Berlin Geowiss Abh E21:1-111

Matyszkiewicz J, Felisiak I (1992) Microfacies and diagenesis of an Upper Oxfordian carbonate buildup in Mydlniki (Cracow area, Southern Poland). Facies 27:179-190 
Matyszkiewicz J, Krajewski M, Kędzierski J (2006a) Origin and evolution of an Upper Jurassic complex of carbonate buildups from Zegarowe Rocks (Kraków-Wieluń Upland, Poland). Facies 52:249-263

Matyszkiewicz J, Krajewski M, Żaba J (2006b) Structural control on the distribution of Upper Jurassic carbonate buildups in the Kraków-Wieluń Upland (south Poland). N Jb Geol Paläont Mon 3:182-192

Matyszkiewicz J, Kochman A, Duś A (2012) Influence of local sedimentary conditions on development of microbialites in the Oxfordian carbonate buildups from the southern part of the Kraków-Częstochowa Upland (south Poland). Sediment Geol 263-264:109-132

Matyszkiewicz J, Kochman A, Rzepa G, Gołębiowska B, Krajewski M, Gajdzik K, Żaba J (2015) Epigenetic silicification of the Upper Oxfordian limestones in the Sokole Hills (KrakówCzęstochowa Upland): relationship to facies development and tectonics. Acta Geol Pol 65:181-203

Migaszewski ZM, Gałuszka A, Durakiewicz T, Starnawska E (2006) Middle Oxfordian-Lower Kimmeridgian chert nodules in the Holy Cross Mountains, south-central Poland. Sediment Geol 187:11-28

Montenat Ch, Barrier P, Ott d'Estevou P, Hibsch Ch (2007) Seismites: an attempt at critical analysis and classification. Sediment Geol 196:5-30

Neuweiler F, Borque PA, Boulvain F (2001) Why is stromatactis so rare in Mesozoic carbonate mud mounds? Terra Nova 13:338-346

Niemczycka T, Brochwicz-Lewiński W (1988) Evolution of the Upper Jurassic sedimentary basin in the Polish Lowlands. Geol Q 32:137-155 (in Polish with English summary)

Olchowy P (2011) Possible origin of stromatactis-like cavities in Upper Jurassic sediments from the Wielkanoc quarry near Gołcza (Kraków-Częstochowa Upland, southern Poland)experimental studies. Facies 57:613-625

Olivier N, Carpentier C, Martin-Garin B, Lathuilliere B, Gaillard C, Ferry S, Hantzpergue P, Geister J (2004) Coral-microbialite reefs in pure carbonate versus mixed carbonate-siliciclastic depositional environments: the example of the Pagny-sur-Meuse section (Upper Jurassic, northeastern France). Facies 50:229-255

Olivier N, Pittet B, Werner W, Hantzpergue P, Gaillard Ch (2008) Facies distribution and coral-microbialite reef development on a low-energy carbonate ramp (Chay Peninsula, Kimmeridgian, western France). Sediment Geol 205:14-33

Olivier N, Colombié C, Pittet B, Lathuilière B (2011) Microbial carbonates and corals on the marginal French Jura platform (Late Oxfordian, Molinges section). Facies 57:469-492

Olóriz F, Reolid M, Rodríguez-Tovarm FJ (2003) A Late Jurassic carbonate ramp colonized by sponges and benthic microbial communities (External Prebetic, Southern Spain). Palaios $18: 428-545$

Olszewska B, Matyszkiewicz J, Król K, Krajewski M (2012) Correlation of the Upper Jurassic-Cretaceous epicontinental sediments in southern Poland and south western Ukraine based on thin sections. Biul Inst Geol 453:29-80

Pittet B, Mattioli E (2002) The carbonate signal and calcareous nannofossil distribution in an Upper Jurassic section (Balingen-Tieringen, Late Oxfordian, southern Germany). Palaeogeogr Palaeoclimatol Palaeoecol 179:71-96

Pleş G, Mircescu CV, Bucur II, Sǎsăran E (2013) Encrusting microorganisms and microbial structures in Upper Jurassic limestones from the Southern Carpathians (Romania). Facies 59:19-48

Pożaryski W, Brochwicz-Lewiński W, Brodowicz Z, JaśkowiakSchoeneichowa M, Milewicz J, Sawicki L, Uberna T (1979) Geological map of Poland and adjoining countries without Cenozoic formations 1:1,000,000. Geol Inst, Warszawa (in Polish)
Reolid M, Gaillard Ch (2007) Microfacies, microtaphonomic traits and foraminiferal assemblages from Upper Jurassic ooliticcoral limestones: stratigraphic fluctuations in a shallowingupward sequence (French Jura, Middle Oxfordian). Facies 53:553-574

Reolid M, Gaillard Ch, Olóriz F, Rodríguez-Tovar FJ (2005) Microbial encrustations from the Middle Oxfordian-earliest Kimmeridgian lithofacies in the Prebetic Zone (Betic Cordillera, southern Spain): characterization, distribution and controlling factors. Facies 50:529-543

Riding R (2002) Structure and composition of organic reefs and carbonate mud mounds: concepts and categories. Earth Sci $58: 163-231$

Roniewicz E (2004) Jurassic corals in Poland. Tomy Jurajskie 2:8397 (in Polish with English summary)

Roniewicz E, Roniewicz P (1971) Upper Jurassic coral assemblages of the central Polish Uplands. Acta Geol Polon 21:399-423

Salamon M, Gorzelak P (2010) Late Cretaceous crinoids (Crinoidea) from Eastern Poland. Palaeontogr Abt A 291:1-43

Schlagintweit F, Gawlick HJ (2008) The occurrence and role of microencruster frameworks in Late Jurassic to Early Cretaceous platform margin deposits of the Northern Calcareous Alps (Austria). Facies 54:207-231

Schlagintweit F, Bover-Arnal T, Salas R (2010) New insights into Lithocodium aggregatum Elliott 1956 and Bacinella irregularis Radoičić 1959 (Late Jurassic-Lower Cretaceous): two ulvophycean green algae (?Order Ulotrichales) with a heteromorphic life cycle (epilithic/euendolithic). Facies 56:509-547

Schmid DU (1996) Marine mikrobolithe und mikroinkrustierer aus dem Oberjura. Profil 9:101-251

Schmid DU, Leinfelder RR, Nose M (2001) Growth dynamics and ecology of Upper Jurassic mounds, with comparisons to MidPalaeozoic mounds. Sediment Geol 145:343-376

Senowbari-Daryan B, Bucur II, Schlagintweit F, Săsăran E, Matyszkiewicz J (2008) Crescentiella, a new name for "Tubiphytes" morronensis CRESCENTI, 1969: an enigmatic Jurassic-Cretaceous microfossil. Geol Croat 61:185-214

Trammer J (1989) Middle to upper Oxfordian sponges of the Polish Jura. Acta Geol Polon 39:49-91

Védrine S, Strasser A, Hug W (2007) Oncoid growth and distribution controlled by sea-level fluctuations and climate (Late Oxfordian, Swiss Jura Mountains). Facies 53:535-552

Wierzbowski A, Matyja BA, Ślusarczyk-Radwan D (1983) New data on Upper Jurassic strata in the Wielun Upland and vicinities of Burzenin and their economic value. Geol Q 27:517-534 (in Polish with English summary)

Żaba J (1999) The structural evolution of Lower Paleozoic succession in the Upper Silesia Block and Małopolska Block border zone, southern Poland. Prace Państw Inst Geol 166:1-162 (in Polish with English summary)

Żelaźniewicz A, Aleksandrowski P, Buła Z, Karnkowski PH, Konon A, Oszczypko N, Ślączka A, Żaba J, Żytko K (2011) Regionalizacja tektoniczna Polski. Komitet Nauk Geologicznych PAN, Wrocław

Ziegler PA (1990) Geological atlas of western and central Europe. Shell Intern Petrol Maatsch BV The Hague, pp $239+56$ enclosures

Ziółkowski P (2007) Stratygrafia i zróżnicowanie facjalne górnej jury wschodniej części Wyżyny Krakowskiej. Tomy Jurajskie 4:2538 (in Polish)

Złonkiewicz Z (2009) The Callovian and Upper Jurassic section in the Nida Trough. Prz Geol 57:521-530 (in Polish with English summary) 